\title{
Combined biogeophysical and biogeochemical effects of large-scale forest cover changes in the MPI earth system model
}

\author{
S. Bathiany ${ }^{1,2}$, M. Claussen ${ }^{1,3}$, V. Brovkin ${ }^{1}$, T. Raddatz ${ }^{1}$, and V. Gayler ${ }^{1}$ \\ ${ }^{1}$ Max Planck Institute for Meteorology, KlimaCampus, Hamburg, Germany \\ ${ }^{2}$ School of Integrated Climate System Sciences, KlimaCampus, University of Hamburg, Hamburg, Germany \\ ${ }^{3}$ Meteorological Institute, KlimaCampus, University of Hamburg, Hamburg, Germany
}

Received: 27 November 2009 - Published in Biogeosciences Discuss.: 18 January 2010

Revised: 14 April 2010 - Accepted: 19 April 2010 - Published: 4 May 2010

\begin{abstract}
Afforestation and reforestation have become popular instruments of climate mitigation policy, as forests are known to store large quantities of carbon. However, they also modify the fluxes of energy, water and momentum at the land surface. Previous studies have shown that these biogeophysical effects can counteract the carbon drawdown and, in boreal latitudes, even overcompensate it due to large albedo differences between forest canopy and snow. This study investigates the role forest cover plays for global climate by conducting deforestation and afforestation experiments with the earth system model of the Max Planck Institute for Meteorology (MPI-ESM). Complete deforestation of the tropics $\left(18.75^{\circ} \mathrm{S}-15^{\circ} \mathrm{N}\right)$ exerts a global warming of $0.4^{\circ} \mathrm{C}$ due to an increase in $\mathrm{CO}_{2}$ concentration by initially $60 \mathrm{ppm}$ and a decrease in evapotranspiration in the deforested areas. In the northern latitudes $\left(45^{\circ} \mathrm{N}-90^{\circ} \mathrm{N}\right)$, complete deforestation exerts a global cooling of $0.25^{\circ} \mathrm{C}$ after 100 years, while afforestation leads to an equally large warming, despite the counteracting changes in $\mathrm{CO}_{2}$ concentration. Earlier model studies are qualitatively confirmed by these findings. As the response of temperature as well as terrestrial carbon pools is not of equal sign at every land cell, considering forests as cooling in the tropics and warming in high latitudes seems to be true only for the spatial mean, but not on a local scale.
\end{abstract}

\section{Introduction}

As greenhouse gas concentrations are increasing rapidly, it is often discussed how carbon sinks can be generated in addition to emission reductions. In this regard, the terrestrial biosphere plays an important role. It is estimated to have

Correspondence to: S. Bathiany (sebastian.bathiany@zmaw.de) stored about $166 \mathrm{GtC}$ (about 34\% of total anthropogenic carbon) during the last two centuries, while total emissions of $200 \mathrm{GtC}$ are attributed to deforestation in this period (House, 2002). The Kyoto Protocol takes afforestation into account by considering such changes in carbon pools. As Pielke et al. (2002) point out, carbon has thus become the currency to assess the human influence on global climate. However, the vegetation cover also affects important parameters of the land surface such as albedo, roughness length and hydrological properties (Nobre et al., 2004; Pielke et al., 1998). With few exceptions, the albedo of forest canopies is lower than the albedo of other vegetation or bare soil (Alton, 2009). Therefore, the net radiation at the surface tends to be larger which acts to increase near ground temperatures. In boreal latitudes, albedo differences are particularly large when snow is present, as the snow cover may be partly masked by trees but not by herbaceous vegetation. In the tropics, the influence of forests on the water cycle is also important: tropical forests are characterised by large evapotranspiration (ET) which acts to cool the surface. Due to deep roots, soil moisture can be returned to the atmosphere more efficiently (Nobre et al., 2004). In addition, trees increase the surface roughness, which leads to larger diffusive fluxes. Without further feedbacks, this would also lead to a cooling because the loss of energy has to be compensated by the surface net radiation. On the other hand, changes in wind speed and direction can lead to circulation changes (Sud et al., 1996), whose impact on temperature is less definite. Which mechanism prevails is a result of many nonlinear interactions and thus critically depends on the imposed changes and the original climate (Pitman et al., 2004). Moreover, these biogeophysical effects are linked to changes in the carbon cycle (biogeochemical effects) by several processes such as the dependence of transpiration on productivity and the dependence of plant physiology and structure on atmospheric $\mathrm{CO}_{2}$ concentration (Betts et al., 1997).

Published by Copernicus Publications on behalf of the European Geosciences Union. 
Studies of the net effect of historical land cover change on global temperature have shown that biogeophysical and biogeochemical mechanisms are of the same order of magnitude (Matthews et al., 2004; Brovkin et al., 2006). Therefore, in order to quantifiy the impacts of large scale land cover changes appropriately, both effects should also be included. Claussen et al. (2001) used the intermediate complexity model CLIMBER-2 to implement a complete afforestation and deforestation in different latitude bands. A factor separation yielded a cooling biogeochemical, but a warming biogeophysical contribution of increased forest cover in each latitude. With combined effects they found a temperature decrease (increase) resulting from afforestation (deforestation) in the tropics but the opposite effect in high northern latitudes. This result was confirmed by Bala et al. (2007), who applied a GCM with a coupled carbon cycle (INCCA). Betts (2000) used the radiative transfer model of HadAM3 to estimate the radiative forcing due to afforestation with conifer plantations in boreal latitudes. His geographically explicit calculation indicates that the masking of snow may not be the dominant mechanism everywhere, although on average a mean positive forcing was obtained. Other studies even challenge the warming influence of boreal forests for larger scales: Schaeffer et al. (2006) analysed the possibilities of extratropical afforestation based on socio-economically realistic scenarios for the 21 st century. Their study demonstrates that the different time scales of biogeophysical and biogeochemical effects have to be considered. While the decrease in albedo dominates the temperature response in the first half of the century, global mean surface air temperature is reduced in 2100. Bird et al. (2008) developed a conceptual standbased model and obtain a net cooling from year 40 on when the model is applied to several sites in Canada. As the main reason they identify the high cloud cover in spring which diminishes the surface forcing despite large albedo differences. Further objection is presented by Spracklen et al. (2008), who argue that the emission of cloud condensation nuclei from trees can cause a negative radiative forcing of several $\mathrm{W} / \mathrm{m}^{2}$ due to direct and indirect aerosol effects. Montenegro et al. (2009) used satellite observations to infer the potential net effect of small scale afforestation projects. They came to the conclusion that in all latitudes $\mathrm{CO}_{2}$-sequestration is the dominating mechanism with a mean efficiency of $50 \%$. Furthermore, no clear dependency on latitude was found. Considering these results, it seems definite that albedo differences counteract the carbon drawdown of afforestation in boreal latitudes and that biogeophysical effects should also not be neglected in other regions. However, the sign and amplitude of the global mean temperature response remains subject to many uncertainties.

In the following, the earth system model of the Max Planck Institute for Meteorology, MPI-ESM, is used to study the sensitivity of the coupled system to large scale changes in forest cover. Apart from Bala et al. (2007), such an analysis has not yet been performed with a fully coupled AOGCM.
In addition to the model differences, the longer integration time and the comparison to an anthropogenically undisturbed climate, this study differs from Bala et al. (2007) by considering afforestation as well as deforestation experiments, whereas biogeophysical and biogeochemical contributions are not calculated separately. Section 2 gives a short description of the model and the implementation of the experiments. The resulting changes in global mean temperature and the carbon cycle are presented in Sect. 3.1, while regional biogeophysical mechanisms and their feedbacks on the carbon cycle are presented in Sect. 3.2. In Sect. 4 these results are discussed with regard to previous studies of large-scale land cover changes, while final conclusions are drawn in Sect. 5.

\section{Model and experiment setup}

MPI-ESM consists of the atmosphere general circulation model ECHAM5 (Roeckner et al., 2003), the land surface model JSBACH (Raddatz et al., 2007), the ocean model MPIOM (Jungclaus et al., 2006) and the ocean biogeochemistry model HAMOCC5 (Maier-Reimer et al., 2005). ECHAM5 was run in T31 resolution $\left(3.75^{\circ}\right)$ with 19 vertical levels, MPIOM with approx. $3^{\circ}$ and 40 vertical levels. JSBACH includes a dynamic vegetation module (Brovkin et al., 2009) which is based on a tiling approach. Within the vegetated fraction of each grid box eight different plant functional types (PFTs) are considered: tropical and extratropical trees (both deciduous and evergreen), raingreen and cold shrubs, and C3- and C4-grasses. Seven pools of land carbon are distinguished in the model: a green pool, a reserve pool and a woody pool (the sum of these is referred to as living biomass), two litter pools and two soil pools. The photosynthesis scheme is based on Farquhar (1980) and for C4-grass on Collatz (1992). Soil respiration is calculated according to a $\mathrm{Q}_{10}$-model and is linearly dependent on soil moisture, which is represented by a "bucket" approach. Physical land surface parameters such as albedo and roughness length are calculated from the individual properties of the PFTs and bare ground, weighted with their cover fractions for each land grid cell.

The equilibrium $\mathrm{CO}_{2}$ concentration in the control run (CTL) amounts to $275 \mathrm{ppm}$. Orbital parameters were kept fixed at present day values and no anthropogenic land use was prescribed. Compared to observations, forest cover (Fig. 1) is distributed reasonably well in most parts of the globe (Brovkin, 2009). However, the equilibrium carbon storage (Fig. 2) differs from observations: In comparison with Prentice et al. (2001), the model underestimates carbon pools of plants and litter in boreal latitudes $\left(2-6 \mathrm{~kg} / \mathrm{m}^{2}\right.$ instead of a mean of $4-6 \mathrm{~kg} / \mathrm{m}^{2}$ ), while soil carbon is too large in central and eastern Asia. In the tropics, vegetation carbon seems to be better represented, while soil carbon pools of $20-40 \mathrm{~kg} / \mathrm{m}^{2}$ exceed observations by a factor of 2 . 
Starting from this state, four 300 year experiments were conducted: tropical deforestation (DT), tropical afforestation (AT), boreal deforestation (DB) and boreal afforestation $(\mathrm{AB})$. The term "tropical" here refers to the area between $18.75^{\circ} \mathrm{S}$ and $15^{\circ} \mathrm{N}$, the "boreal" land cover change is applied between $45^{\circ} \mathrm{N}$ and $90^{\circ} \mathrm{N}$. The latitudinal bands where chosen with regard to the distribution of forest PFTs in the model. In the deforestation cases, all PFTs but grass types were removed. In the afforestation cases, all PFTs but forest types were removed and the total vegetation cover was set to $100 \%$ in the areas under consideration except on ice shields. In all cases, the cover fractions of the remaining PFTs were then increased while keeping their relative composition fixed. In the case of boreal afforestation this procedure fails for grid cells, where no forest had previously existed. At these cells, deciduous and evergreen extratropical forest were taken with cover fractions of 50\% each. As a result of the applied method, tree cover was expanded towards unproductive regions in the afforestation experiments. Since changes in biogeophysical parameters such as albedo and transpiration were calculated on a basis of changes in the carbon cycle, relative effects of afforestation are expected to be less than the deforestation effects. In all experiments, the new distribution of PFTs was kept fixed in the affected areas. For the other land cells, dynamic vegetation was still active.

The land cover change module of JSBACH was used to calculate the respective initial values of the carbon pools. Half of the vegetation carbon of the removed PFTs was relocated to the atmosphere within the first year. The other half was immediately put into the soil pools. Carbon from litter and soil pools was transferred from removed tiles to expanded tiles. At the same time, the carbon densities of expanding tiles were reduced, so that there was no immediate carbon flux between these tiles and the atmosphere. As expected, the time scale of emissions is thus much faster than the time scale of sequestration, because plants have to accumulate carbon according to their productivity.

\section{Results}

\subsection{Global changes in temperature and the carbon cycle}

As a result of tropical deforestation, global mean temperature is increased by approx. $0.4^{\circ} \mathrm{C}$; the warming in high latitudes is particularly pronounced due to greenhouse forcing (Fig. 3). Because living carbon pools and forest cover are large in the tropics, the $\mathrm{CO}_{2}$ increase of initially $60 \mathrm{ppm}$ is much higher than in DB (Fig. 4). Changes in the ocean's carbon content are primarily a result of the $\mathrm{CO}_{2}$-anomalies and not shown here; Fig. 5 depicts the changes in global terrestrial carbon. It is evident that DT is not only characterised by large primary emissions of approx. $123 \mathrm{GtC}$ due to biomass reduction, but also by net secondary emissions due to soil decomposition of almost the same amount. In fact, in the end of the experi-

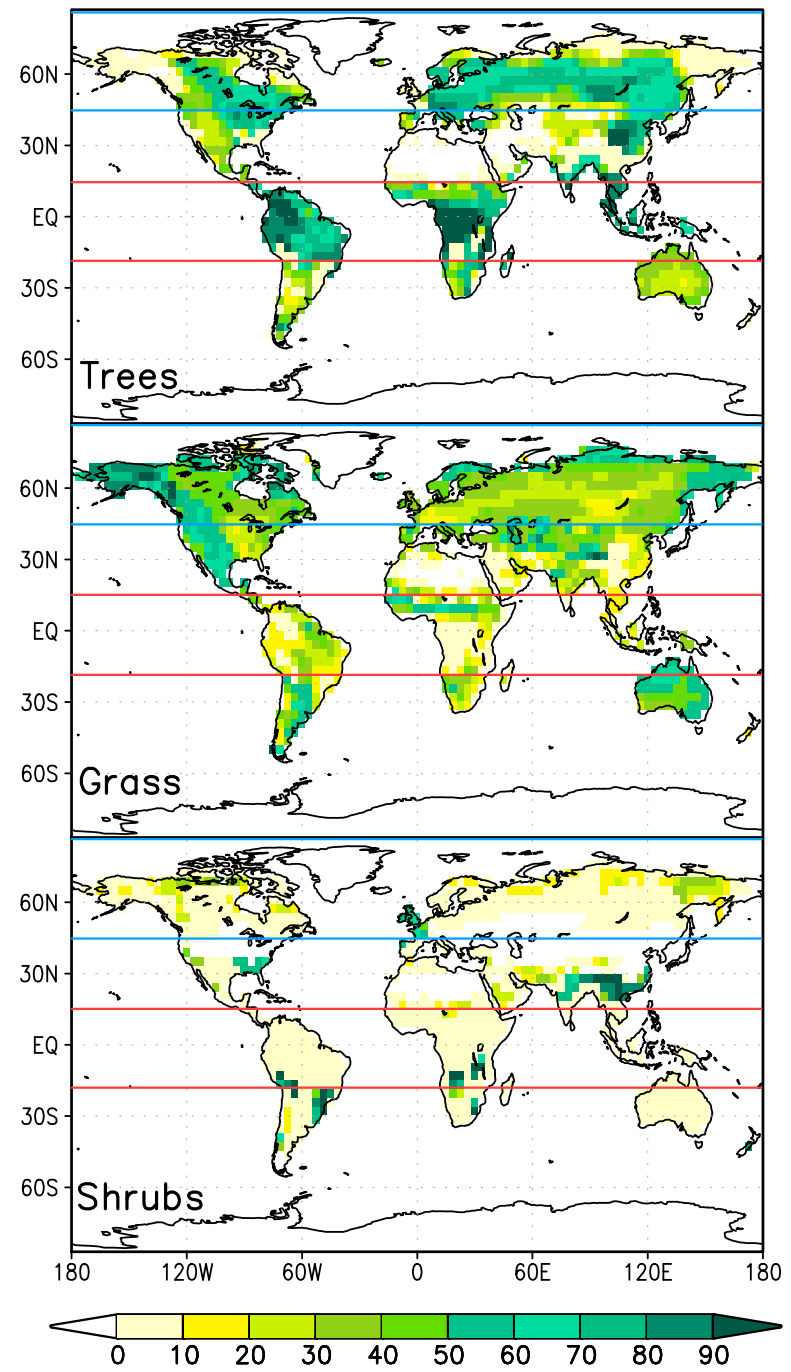

Fig. 1. Distribution of natural potential trees, grass and shrubs in the control experiment. Displayed is the fraction of each grid cell covered by the according vegetation. The blue and red lines contain the areas affected in the boreal and tropical experiments, respectively.

ment, tropical land cells contain $390 \mathrm{GtC}$ less than in CTL, of which the extratropical regions compensate $190 \mathrm{GtC}$ (Fig. 6). During the first decades, the emissions from tropical soils are almost exactly balanced by the extratropical land and ocean sinks. This explains the constant $\mathrm{CO}_{2}$ concentration in Fig. 4. As these sinks change on a larger time scale than the tropical land areas, they prevail after some 60 to 80 years and $\mathrm{CO}_{2}$ concentration decreases. Around the year 90, extratropical land regions alone overcompensate the tropical sink, so that terrestrial carbon increases again. This extratropical sink is due to $\mathrm{CO}_{2}$-fertilisation, higher temperatures and, in some regions, a northerly shift of boreal forest.

In comparison to DT, terrestrial carbon pool anomalies are small in AT. Tropical land areas take up approx. $0.33 \mathrm{GtC} / \mathrm{yr}$, decreasing atmospheric $\mathrm{CO}_{2}$ by only $5 \mathrm{ppm}$ within some 


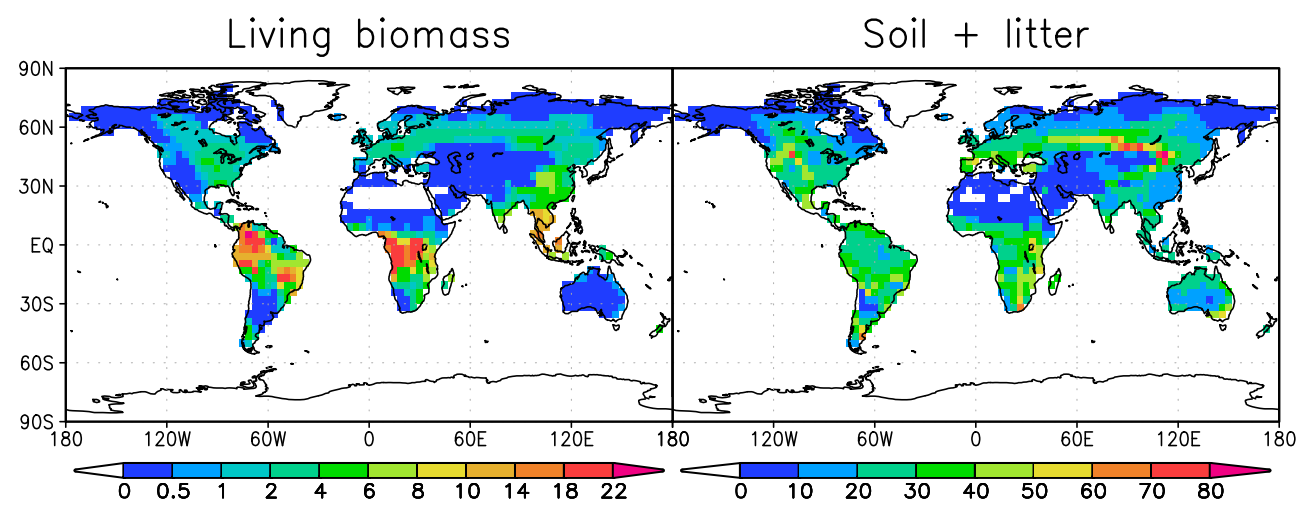

Fig. 2. Carbon storages in $\mathrm{kg} / \mathrm{m}^{2}$ for different pools of the control run.
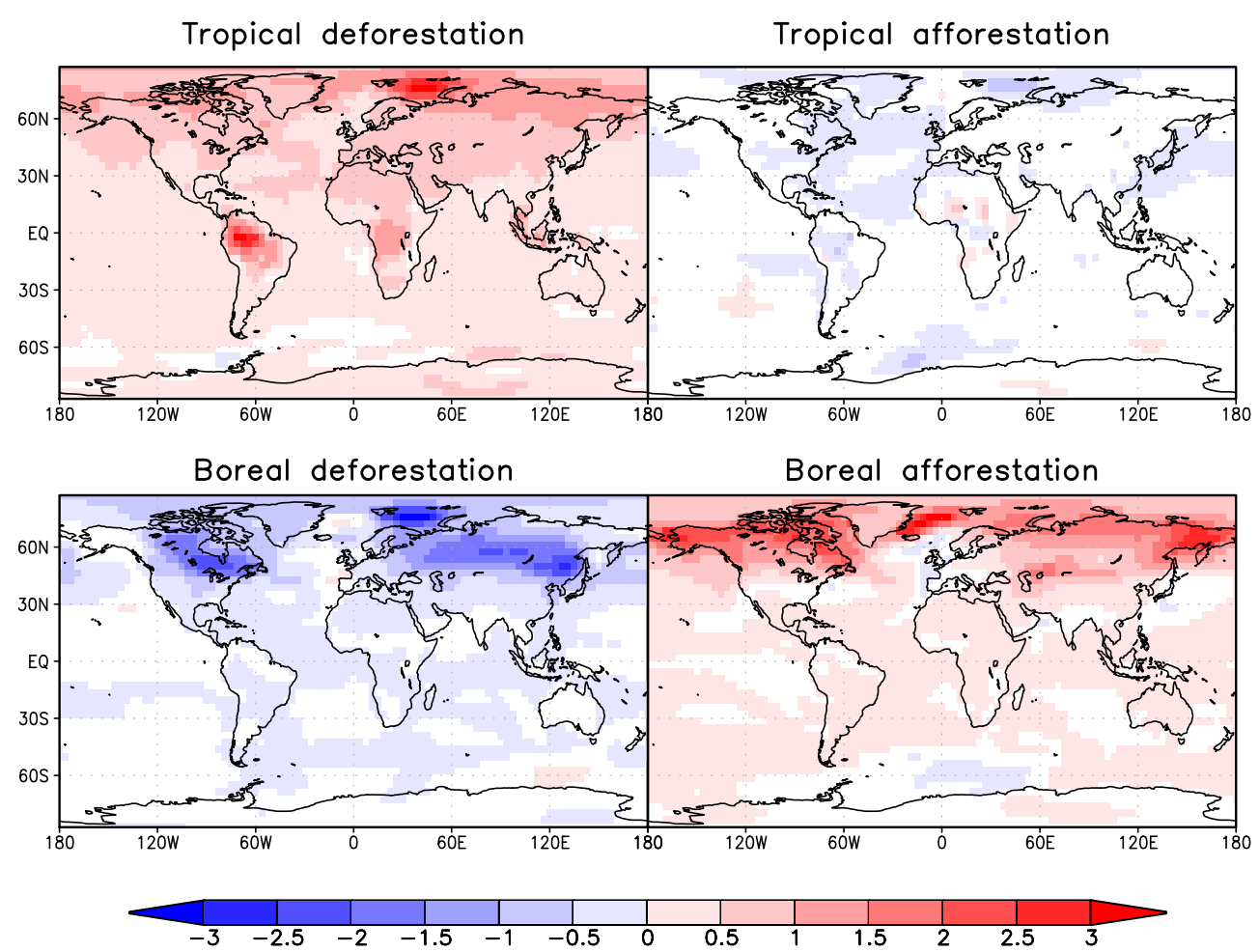

Fig. 3. Anomalies in $2 \mathrm{~m}$-temperature averaged over the final 200 years for each experiment. White areas show no significant changes according to a t-test with $95 \%$ significance.

decades. Thereafter, net emissions by the ocean and the extratropical biosphere are large enough to balance the tropical anomaly which approaches an equilibrium in the final century. Global mean temperature decreases by only $0.06^{\circ} \mathrm{C}$. Changes in AT are much smaller than in DT, because the converted area is smaller. Besides, climatic limitations play a role, as will be discussed in Sect. 3.3.

Things look quite different in the boreal experiments. In DB only approx. $20 \mathrm{GtC}$ are emitted instantaneously due to the lower carbon storage of living biomass in boreal latitudes. The trend in global terrestrial carbon is close to zero because soil respiration in the cold regions is slow enough to be compensated by an enhanced productivity in the tropics. Therefore, the ocean uptake alone is responsible for the reduction of the $\mathrm{CO}_{2}$-anomaly from $10 \mathrm{ppm}$ to $3.7 \mathrm{ppm}$ within the first 60 years. An additional reason for the slow response in the carbon pools of the deforested region is the large proportion of litter. Due to the experiment setup, litter is redistributed to expanding tiles and not put into the soil pools immediately. Because of the increased litter flux during the first decades, soil carbon is first increased before it returns to its original anomaly of $+20 \mathrm{GtC}$ at the end of the experiment. 


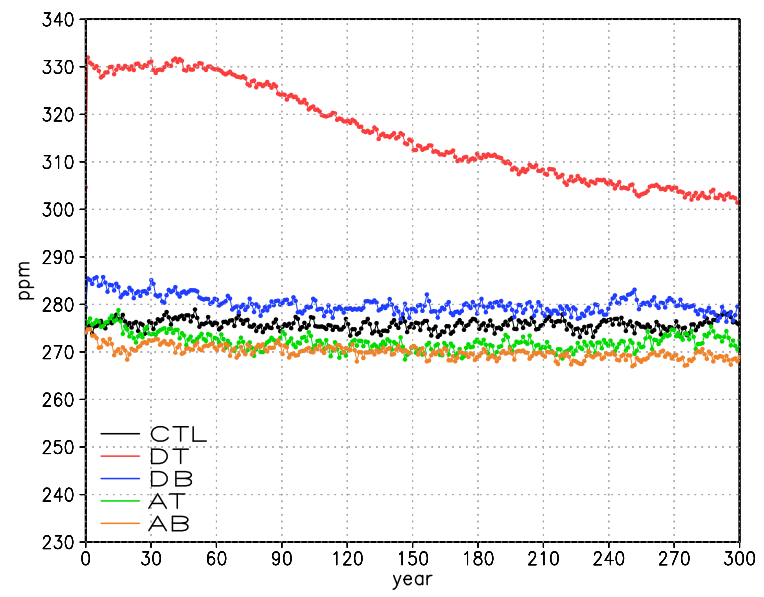

Fig. 4. Evolution of atmospheric $\mathrm{CO}_{2}$ in each experiment.

In the case of $\mathrm{AB}$, extratropical as well as tropical regions exchange much more carbon than in AT. Large areas are available especially in the northern regions, where most additional terrestrial carbon is stored at the end of the experiment (Fig. 6). In the first 15 years $20 \mathrm{GtC}$ are taken up by the biosphere and $\mathrm{CO}_{2}$-concentration is reduced by $5 \mathrm{ppm}$ in this period. Thereafter the tropical and oceanic sources almost compensate the sequestration. While pools of living biomass and litter become saturated at $+35 \mathrm{GtC}$ and $+30 \mathrm{GtC}$ in the last decades, soil carbon increases almost linearly in the final 200 years and already contains $40 \mathrm{GtC}$ more than in CTL in the year 300 . As the time scale of tropical soils is shorter, they compensate a considerable part of the boreal sink (more than $60 \mathrm{GtC}$ by the year 300 ), about twice as much as the ocean. Despite the $\mathrm{CO}_{2}$ forcing, global mean temperature increases in $\mathrm{AB}$ (and decreases in DB) by approx. $0.25^{\circ} \mathrm{C}$. It is thus evident that biogeophysical mechanisms dominate the global mean temperature response in the boreal experiments.

Although global mean terrestrial carbon anomalies are negative after deforestation and positive after afforestation, it is apparent in Fig. 6 that there are regions with a reversed sign. This is due to two reasons: first, plant productivity is altered by the exchange of PFTs and changes in $\mathrm{CO}_{2}$ concentration. Second, the climatic changes feed back on the local carbon pools. By rescaling the carbon pools of the individual tiles in CTL according to their altered cover fractions, the contributions of the PFT exchange alone can be obtained for each experiment. The difference to the actual changes is then due to climate and $\mathrm{CO}_{2}$ feedbacks (neglecting all synergies). These feedbacks can be further separated by inferring changes in NPP and soil respiration with the same method.

The spatial averages of carbon pools in and outside the areas of land cover change are presented in Table 1. For soil carbon, the feedback calculation explained above was applied. The separated impact of the redistribution of cover fractions is refered to as uncoupled. In DT, all contributions act to decrease the tropical carbon pools which explains

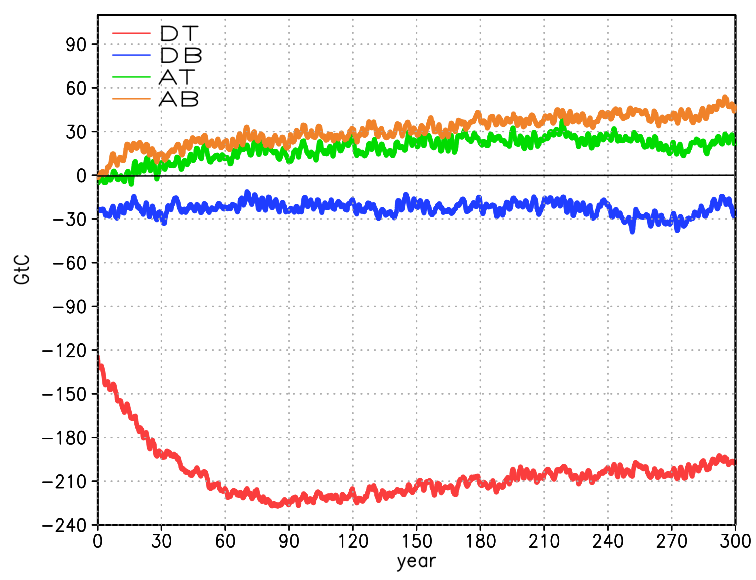

Fig. 5. Evolution of anomalies in global terrestrial carbon in each experiment.

the large secondary emissions in this experiment. Climatecarbon cycle feedbacks reduce the sequestration in AT and $\mathrm{AB}$ (as will be further discussed in Sect. 3.2), while in DB the larger productivity of grass would even lead to a mean gain in boreal soil carbon. Indeed, soil carbon has not at all contributed to secondary emissions by the year 300 , in contrast to the litter pools. It has to be considered though, that soil carbon pools have not reached an equilibrium by the year 300 in DB and AB. The absolute feedback contribution would therefore further decrease, because it is only inferred as a residual.

As an afforestation project in reality will be most efficient in terms of carbon storage where a converted area has the strongest possible carbon uptake, the changes in carbon storage are also calculated with reference to the absolute changes in forest area only (Table 2). In the tropics, deforestation still has a much larger impact on carbon storage than afforestation because of the climatic limitations in the dry regions. In boreal areas, living biomass and litter are also less affected in $\mathrm{AB}$ than in DB. However, additional carbon is stored in the soil. It is evident that in AT and DB, where changes in soil carbon counteract the changes in biomass, the soil anomalies are smaller than in the corresponding experiments DT and $\mathrm{AB}$. The difference between afforestation and deforestation illustrates that for the whole area afforestation still leads to a gain and deforestation to a loss in soil carbon. Moreover, Table 2 documents that in all experiments the global mean anomalies are of the same sign as the immediate change in biomass, despite all productivity differences and feedbacks.

\subsection{Regional mechanisms and feedbacks}

\subsubsection{The tropical energy balance}

Local temperature changes can be understood by analysing the surface energy balance as presented in Table 3: in DT a warming occurs despite of the increase in surface albedo 

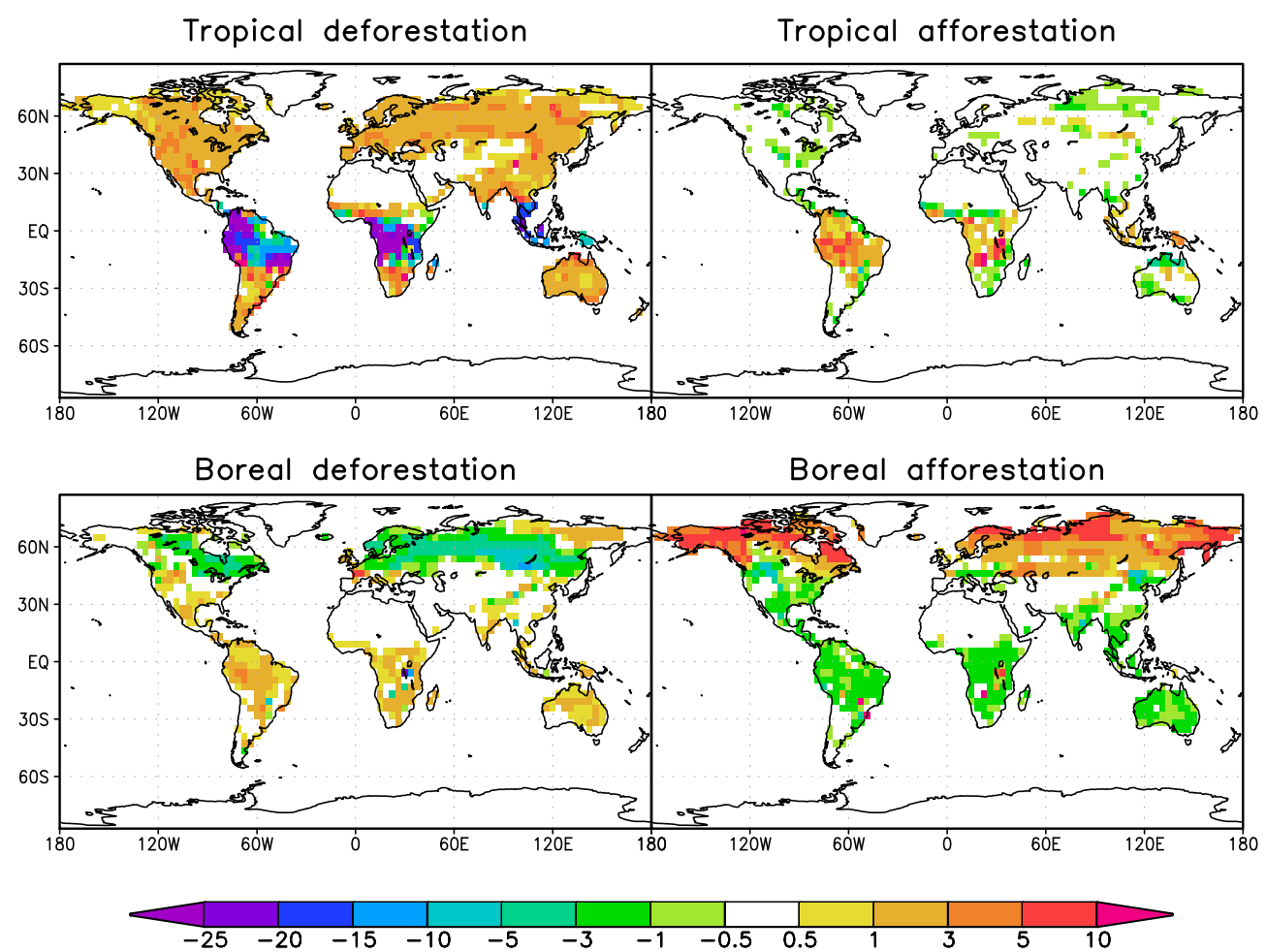

Fig. 6. Total land carbon anomalies in $\mathrm{kg} / \mathrm{m}^{2}$ for each experiment, averaged over the final 10 years.

Table 1. Terrestrial carbon storage anomalies in $\mathrm{kg} / \mathrm{m}^{2}$, averaged over the manipulated land cells and the final 10 years of each experiment (ice sheets not included).

\begin{tabular}{llllll}
\hline Area & Pools & DT & AT & DB & AB \\
\hline Directly affected latitudes & Total & -11.71 & +1.41 & -1.43 & +2.71 \\
& Living biomass and litter & -8.60 & +1.75 & -1.88 & +1.70 \\
& Soil (uncoupled) & -2.46 & +1.24 & +0.33 & +1.38 \\
& Soil (feedbacks only) & -0.64 & -1.58 & +0.12 & -0.37 \\
\hline \multirow{2}{*}{ Other land areas } & Total & +1.74 & -0.20 & +0.42 & -0.68 \\
& Living biomass and litter & +0.27 & -0.01 & +0.12 & -0.07 \\
& Soil & +1.47 & -0.19 & +0.30 & -0.61 \\
\hline \multirow{2}{*}{ Global } & Total & -1.51 & +0.19 & -0.15 & +0.37 \\
& Living biomass and litter & -1.87 & +0.42 & -0.50 & +0.48 \\
& Soil (uncoupled) & -0.60 & +0.30 & +0.10 & +0.43 \\
& Soil (feedbacks only) & +0.96 & -0.53 & +0.24 & -0.54 \\
\hline
\end{tabular}

Table 2. Terrestrial carbon storage anomalies in $\mathrm{kg} / \mathrm{m}^{2}$, averaged over the areas of changed forest cover and the final 10 years of each experiment (ice sheets not included).

\begin{tabular}{lllrrrr}
\hline Pools & DT & AT & AT-DT & DB & AB & AB-DB \\
\hline Total & -16.66 & 4.39 & 21.05 & -3.06 & 4.46 & 7.52 \\
Living biomass and litter & -12.23 & 5.45 & 17.68 & -4.02 & 2.80 & 6.82 \\
Soil (uncoupled) & -3.5 & 3.86 & 7.36 & 0.71 & 2.27 & 1.56 \\
Soil (feedbacks only) & -0.91 & -4.92 & -4.01 & 0.06 & -0.61 & -0.67 \\
Soil, total & -4.41 & -1.06 & 3.35 & 0.77 & 1.66 & 0.89 \\
\hline
\end{tabular}


Table 3. The surface energy balance averaged over tropical and boreal land cells. Values for the experiments are given as deviations from the control climate. All fluxes are in $\mathrm{W} / \mathrm{m}^{2}$, surface temperature in ${ }^{\circ} \mathrm{C}$. For DT, the time periods $11-60$ and $271-300$ have been considered separately, all other runs are averaged over the years $11-300 . \alpha_{\text {surf }}=$ surface albedo, $\alpha_{\mathrm{TOA}}=$ planetary albedo, $\mathrm{SW}=$ short-wave, LW $=$ longwave, $R_{\mathrm{n}}=$ net radiation, $\mathrm{SH}=$ sensible heat flux, $\mathrm{LH}=$ latent heat flux, $T_{\text {surf }}=$ surface temperature.

\begin{tabular}{llllllllllll}
\hline & \multicolumn{3}{c}{ Tropics $\left(18.75^{\circ} \mathrm{S}-15^{\circ} \mathrm{N}\right)$} & \multicolumn{3}{c}{ Boreal $\left(45^{\circ} \mathrm{N}-90^{\circ} \mathrm{N}\right)$} & \multicolumn{3}{c}{ Boreal, MAM } \\
& $\mathrm{CTL}$ & $\Delta \mathrm{DT}$ & $\Delta \mathrm{DT}$ & $\Delta \mathrm{AT}$ & $\mathrm{CTL}$ & $\Delta \mathrm{DB}$ & $\Delta \mathrm{AB}$ & $\mathrm{CTL}$ & $\Delta \mathrm{DB}$ & $\Delta \mathrm{AB}$ \\
& & $\mathrm{yr} 11-60$ & $\mathrm{yr} 271-300$ & & & & & & & \\
\hline$\alpha_{\text {surf }}$ & 0.159 & +0.042 & +0.042 & -0.017 & 0.269 & +0.070 & -0.075 & 0.350 & +0.107 & -0.128 \\
$\alpha_{\mathrm{TOA}}$ & 0.316 & +0.004 & +0.007 & -0.003 & 0.471 & +0.017 & -0.018 & 0.493 & +0.023 & -0.023 \\
$\mathrm{SW} \downarrow$ & 215.5 & +8.1 & +6.7 & -2.7 & 96.9 & +3.4 & -2.9 & 134.4 & +11.2 & -11.5 \\
$\mathrm{SW} \uparrow$ & 34.2 & +10.8 & +10.4 & -4.1 & 26.1 & +8.0 & -7.8 & 47.0 & +19.4 & -19.7 \\
net SW & 181.3 & -2.6 & -3.7 & +1.4 & 70.8 & -4.6 & +4.9 & 87.4 & -8.2 & +8.2 \\
$\mathrm{LW} \downarrow$ & 390.4 & +3.0 & +1.9 & +0.4 & 267.0 & -4.1 & +4.4 & 261.7 & -7.6 & +6.5 \\
$\mathrm{LW} \uparrow$ & 453.3 & +7.5 & +5.5 & -0.7 & 305.1 & -4.8 & +5.2 & 299.7 & -7.9 & +6.9 \\
net LW & -62.9 & -4.5 & -3.6 & +1.1 & -38.1 & +0.6 & -0.9 & -38.0 & +0.3 & -0.4 \\
$R_{\mathrm{n}}$ & 118.4 & -7.1 & -7.3 & +2.5 & 32.7 & -3.9 & +4.0 & 49.4 & -7.9 & +7.8 \\
$\mathrm{SH}$ & 39.3 & +2.7 & +1.4 & +0.4 & 8.2 & -1.7 & +1.6 & 15.7 & -2.6 & +3.1 \\
$\mathrm{LH}$ & 79.1 & -9.8 & -8.7 & +2.0 & 22.6 & -2.3 & +2.4 & 23.6 & -4.9 & +4.4 \\
$T_{\text {surf }}$ & 25.8 & +1.2 & +0.9 & -0.1 & -3.7 & -1.1 & +1.2 & -4.5 & -1.9 & +1.7 \\
\hline
\end{tabular}
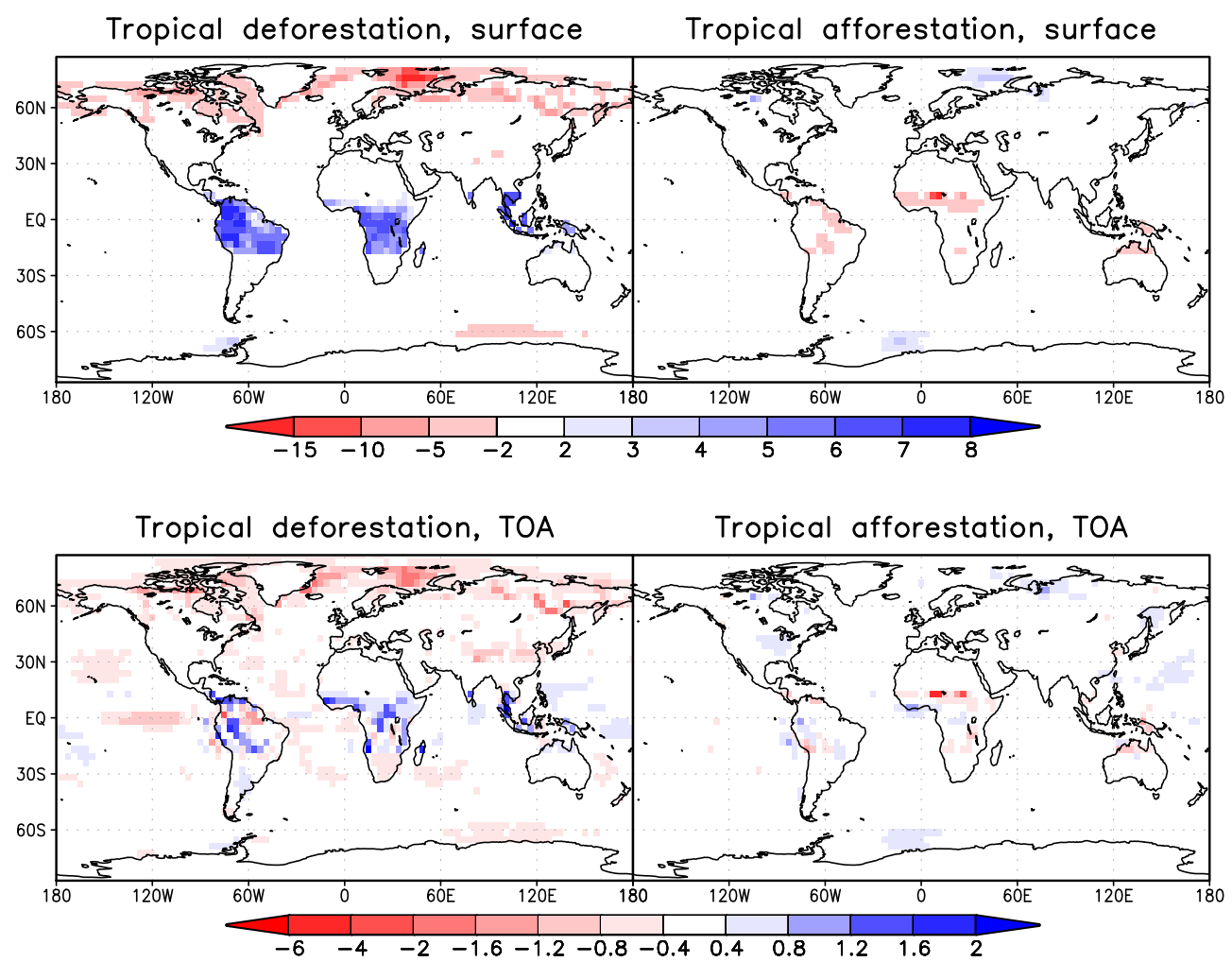

Fig. 7. Anomalies in surface albedo (top) and planetary albedo (bottom) in \%, averaged over the final 200 years for tropical deforestation (left) and tropical afforestation (right).

(Fig. 7). Without any feedbacks, this albedo increase would cause a reduction in net short-wave radiation by approx. $10 \mathrm{~W} / \mathrm{m}^{2}$. Instead, anomalies lie between -8 and $+8 \mathrm{~W} / \mathrm{m}^{2}$ because cloud cover is reduced by up to 0.06 , with a mean of 0.028 over tropical land cells. Hence, the albedo changes at the top of the atmosphere in Fig. 7 are much less uniform. 

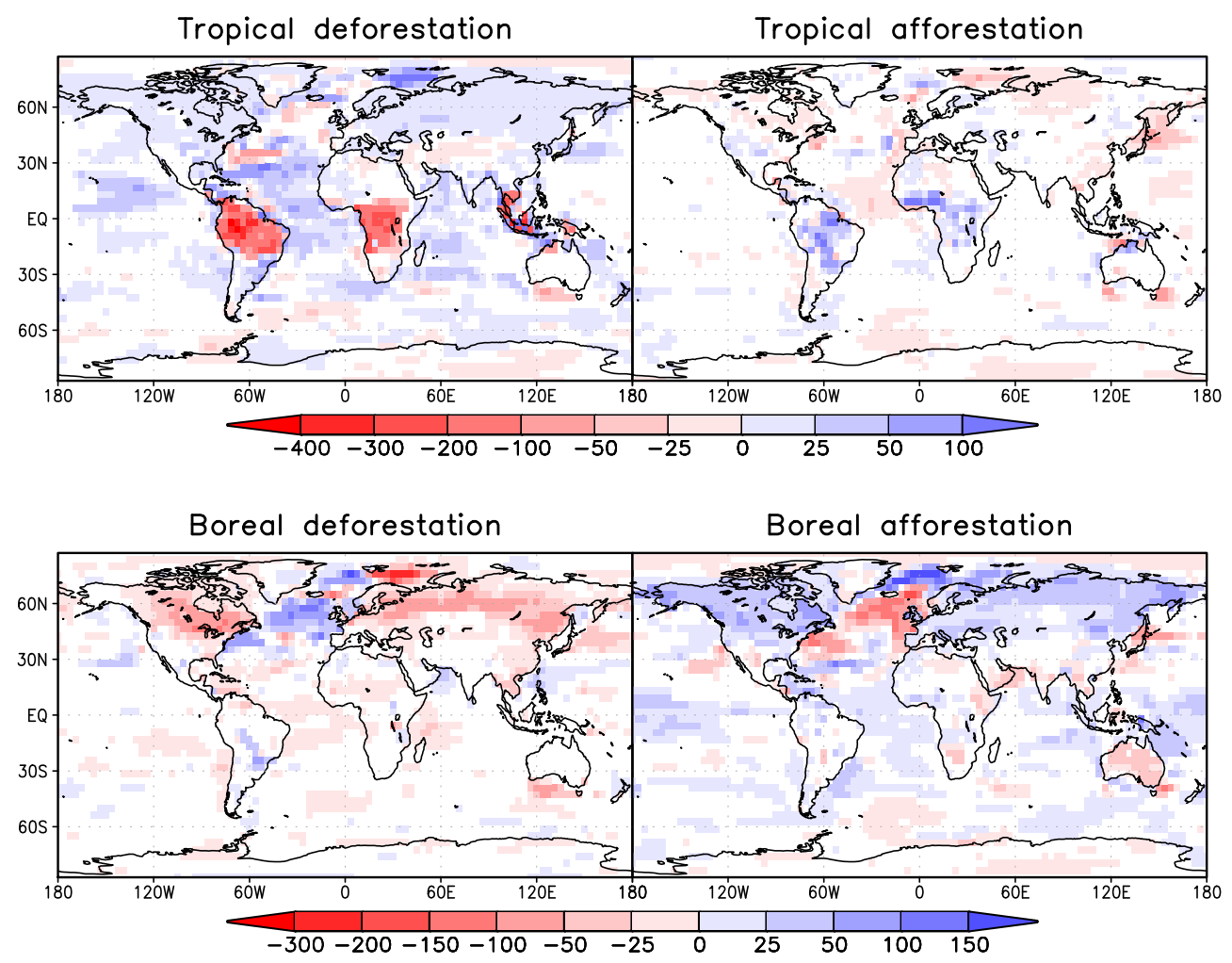

Fig. 8. ET anomalies in mm/year averaged over the final 200 years for each experiment. White areas show no significant changes according to a t-test with $95 \%$ significance.

Due to this cloud feedback, the increased long-wave emission is the most important contribution to the decrease in net radiation at the surface. Because of warmer and drier conditions, the sensible heat flux is increased in DT, despite the reduced net radiation. The lack of energy at the land surface is thus balanced by a strong reduction in ET. In contrast, ET increases over most parts of the ocean because of the global warming (Fig. 8).

Changes in AT are smaller than in DT and generally of opposite sign. However, two exceptions are apparent. Firstly, incoming long-wave radiation increases in both experiments. In AT, this is caused by increased cloud cover which overcompensates the reduced greenhouse effect. In DT, $\mathrm{CO}_{2}$ forcing dominates and despite its decrease towards the end of the experiment, no qualitative changes in the energy balance occur over time (Table 3). The second difference between the experiments concerns the pattern of temperature changes. As Fig. 3 shows, cooling in AT does not take place at every individual land grid cell. In northern Africa, the albedo difference amounts to up to 0.155 (Fig. 7) and net short-wave radiation is increased by $30 \mathrm{~W} / \mathrm{m}^{2}$. This is possible because of the large desert fraction in CTL at the northern boundary of the afforested region. Although ET and cloud cover are increased in northern Africa, the albedo changes have the dominating influence on $2 \mathrm{~m}$-temperature. In southern Africa cloud cover is not changed as uniformly as in other areas, so that in places with decreasing cloud cover and sufficient albedo changes, temperature does also increase. It is due to these warming regions, that the mean change in sensible heat flux is also positive.

\subsubsection{Changes in the tropical water cycle}

Apart from the exceptions mentioned in Sect. 3.2.1 it seems clear that the anomaly in ET is the main driver of temperature changes in the tropical land areas. This is corroborated by the changes in the annual cycle. Because of the seasonal shift of the ITCZ, precipitation mainly occurs in the summer of each hemisphere. Evaporation closely follows precipitation, while transpiration increases during the wet season when buckets are filled with water and stays high during the dry season until soil moisture becomes too small. In the dry period, transpiration contributes to total ET with more than $90 \%$. In DT, temperature is particularly increased during the transition from the rainy to the dry season, when transpiration is reduced the most (Fig. 9 shows results for South America as an example). In addition, the reduction in ET leads to an increase in moisture convergence during March and August, which also dominates the annual mean. As a result, the positive soil moisture anomaly increases and shows the largest value during the moisture minimum after the dry season. In this time of the year, increased soil moisture can 
Table 4. Changes in surface temperature $(T)$, precipitation $(P)$, evapotranspiration $(\mathrm{ET})$ and moisture convergence $(P$-ET) in the Amazon (Am), central Amazon (Am-cent), tropical Africa (Af), South-Eastern Asia (SEA) and the whole tropics (Trop) in the years 11-300. Am-cent consists of 8 grid cells with the boundaries $73^{\circ} \mathrm{W}, 58^{\circ} \mathrm{W}, 7.5^{\circ} \mathrm{S}$ and the equator.

\begin{tabular}{lllll}
\hline $\begin{array}{l}\text { Area and } \\
\text { Experiment }\end{array}$ & $\Delta T$ & $\Delta P$ & $\Delta \mathrm{ET}$ & $\Delta(P$-ET $)$ \\
& {$\left[{ }^{\circ} \mathrm{C}\right]$} & {$[\mathrm{mm} / \mathrm{yr}]$} & {$[\mathrm{mm} / \mathrm{yr}]$} & {$[\mathrm{mm} / \mathrm{yr}]$} \\
\hline Am (DT) & +1.6 & $-138(9.2 \%)$ & $-160(13.3 \%)$ & $+22(7.5 \%)$ \\
Am (AT) & -0.2 & $+44(3.0 \%)$ & $+29(2.5 \%)$ & $+15(5.1 \%)$ \\
Am-cent (DT) & +3.4 & $-467(25.1 \%)$ & $-342(22.5 \%)$ & $-124(37.1 \%)$ \\
Am-cent (AT) & -0.4 & $+79(4.3 \%)$ & $+32(2.1 \%)$ & $+47(14.0 \%)$ \\
Af (DT) & +1.0 & $-75(8.2 \%)$ & $-87(10.9 \%)$ & $+12(10.4 \%)$ \\
Af (AT) & -0.1 & $+27(3.0 \%)$ & $+24(3.0 \%)$ & $+3(2.9 \%)$ \\
SEA (DT) & +1.0 & $-107(8.5 \%)$ & $-135(12.2 \%)$ & $+28(17.7 \%)$ \\
SEA (AT) & -0.1 & $+20(1.6 \%)$ & $+23(2.1 \%)$ & $-3(1.8 \%)$ \\
Trop (DT) & +1.2 & $-104(8.7 \%)$ & $-122(12.2 \%)$ & $+18(9.5 \%)$ \\
Trop (AT) & -0.1 & $+33(2.8 \%)$ & $+26(2.6 \%)$ & $+7(3.7 \%)$ \\
\hline
\end{tabular}

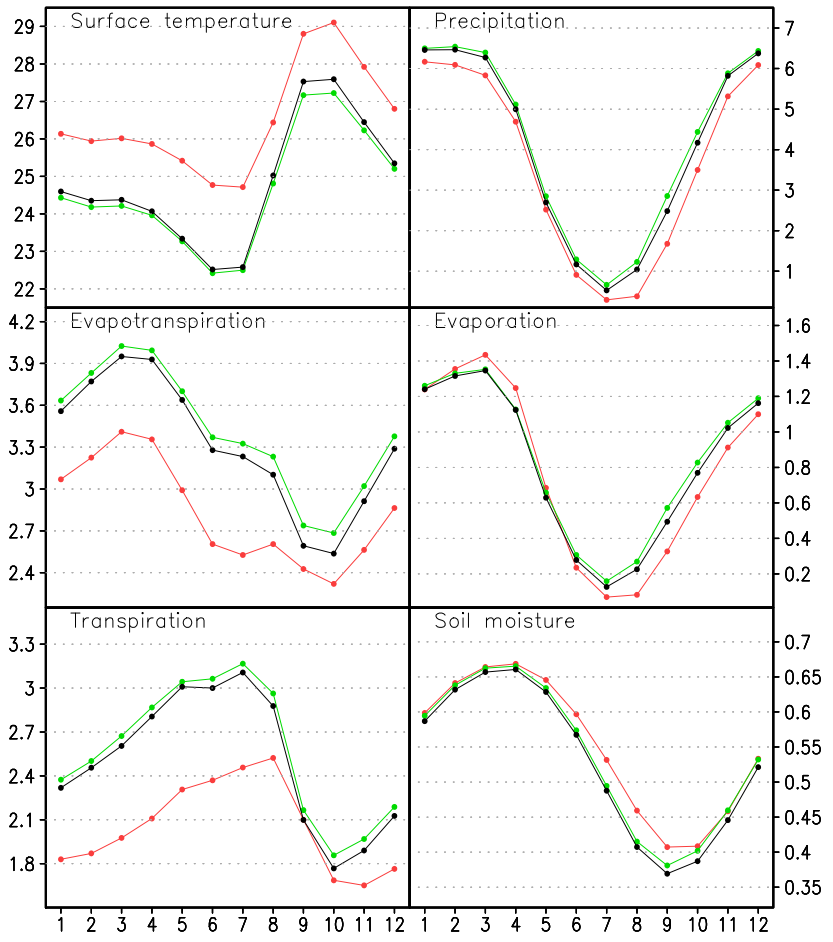

Fig. 9. Annual cycles averaged over the years 11-300 between $18.75^{\circ} \mathrm{S}$ and the equator in South America. Temperature is in ${ }^{\circ} \mathrm{C}$, soil moisture in $\mathrm{m}$, all fluxes in $\mathrm{mm} / \mathrm{day}$. Black: control climate, red: tropical deforestation, green: tropical afforestation.

outweigh the reduced productivity of grass so that transpiration is equal or in some regions even higher than in CTL. The temperature increase is then probably only due to the elevated $\mathrm{CO}_{2}$ concentration.
Table 4 summarises the annual mean changes in precipitation, ET and moisture convergence for different regions. In DT, the decrease in relative humidity and increase in surface albedo act to supress convection which explains the reduced precipitation. A large-scale sinking motion is induced in the mid-troposphere over most tropical land cells, while a rising anomaly occurs over the surrounding tropical oceans with exception of the South Atlantic. In AT, opposite changes are obtained. Table 4 also documents that changes in the centre of Amazonia are different from those in other regions. In central Amazonia, the reduction in precipitation is large enough to exceed that of ET, so that mean moisture convergence and soil moisture decrease. The precipitation decrease during the dry season (Fig. 9) is mostly attributable to this area. Also, ET is decreased in the second half of the year, so that the warming is even stronger during this time, with up to $4^{\circ} \mathrm{C}$ in September. The strong annual mean warming in central Amazonia which is evident in Fig. 3 is the result of these differences in the seasonal cycle. In contrast, the surrounding areas show an increase in soil moisture and moisture convergence as is shown in Fig. 10. While they dominate the spatial mean in DT, this is not the case in AT. Therefore, temperature in AT is mainly decreased (and soil moisture increased) in August and September. Because of the smaller size and the dryer climate of the afforested areas, changes in AT are much smaller than in DT.

The distribution of soil moisture and its changes are also reflected in the tropical land carbon pool anomalies in Fig. 6, Tables 1 and 2. In the dry regions of Northern Australia and Northern Africa, as well as in the north-east of South America, grass is simulated to be more productive than forest, so that deforestation leads to an increase and afforestation to a loss in soil carbon. In addition, the decreased moisture convergence in $\mathrm{AT}$ is accompanied by reduced soil moisture. As a result, total tropical soil carbon in AT decreases, despite 


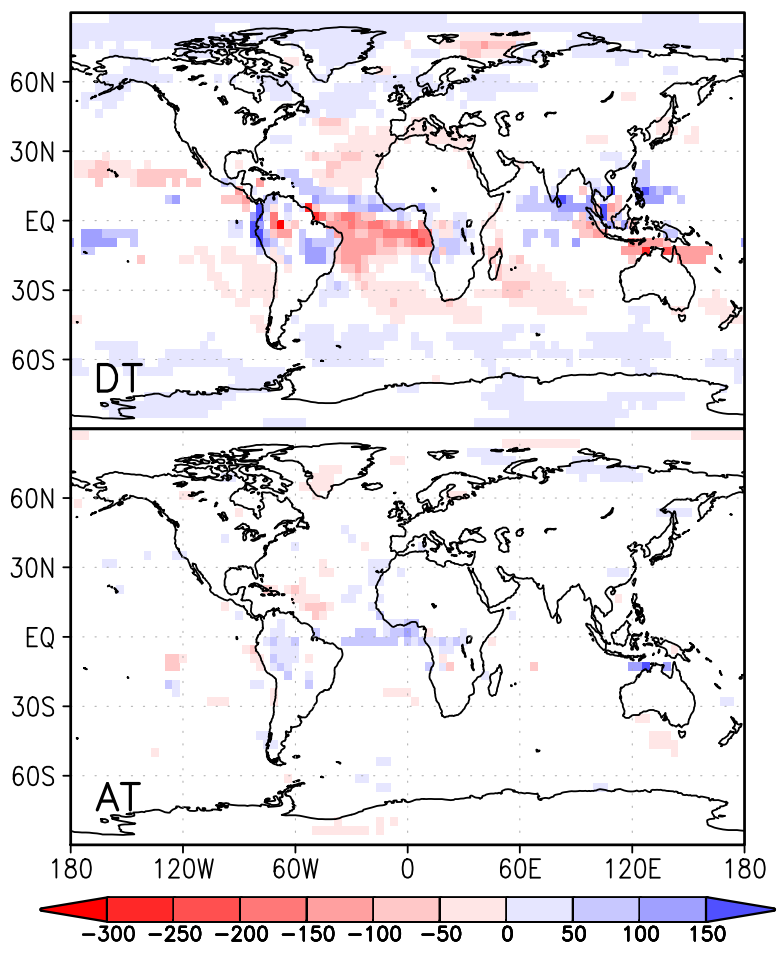

Fig. 10. Changes in annual mean moisture convergence in $\mathrm{mm} / \mathrm{yr}$, averaged over the years 11-300 for tropical deforestation (top) and tropical afforestation (bottom). White areas show no significant changes according to a t-test with $95 \%$ significance.

the fact that more wood carbon tends to increase the turnover time. In the moist tropics, the increase (decrease) in soil moisture in DT (AT) acts to increase NPP with the exception of central Amazonia. Changes in soil moisture also have the largest impact on soil respiration in both experiments, so that respiration changes generally counteract the climatic effects on NPP. For example, in DT central Amazonia shows an increased turnover time even though the strongest warming occurs in this region.

\subsubsection{The boreal energy balance}

In the boreal experiments, temperature is mainly affected by albedo changes due to snow masking (Fig. 11). The effect is strongest in spring when solar insolation is already large while snow cover is still high. As a result, land surface temperature anomalies are at a maximum during this season and reach $3{ }^{\circ} \mathrm{C}$ on zonal average. In DB, snow melt is delayed because of a lower spring temperature, while in $\mathrm{AB}$ it occurs earlier than in CTL (Fig. 12). The mean albedo anomaly is larger in $\mathrm{AB}$ than in $\mathrm{DB}$, as snow cover and converted area in the northern parts are larger. It is due to the lower insolation that temperature does not change more than in the deforestation case. However, the temperature anomaly in $\mathrm{AB}$ stays large until summer, because snow melt occurs later in the north.
Due to the albedo changes the upwelling short-wave radiation is the largest contribution to the changes in net radiation (Table 3). In contrast to the tropics, the long-wave fluxes almost cancel each other. Annual mean changes in cloud cover are also low: DB shows a decrease by 0.003 , $\mathrm{AB}$ an increase by only 0.001 , which is both about one order of magnitude below the changes in the tropical experiments. Therefore, the changes in planetary albedo resemble those in surface albedo (Fig. 13). However, annual mean short-wave insolation does change because of the seasonal and spatial differences in cloud cover. In winter and spring, cloud cover is decreased by deforestation in winter (particularly at the southern edge of the affected area, so that it still exerts a radiative effect) and increased in summer.

The cloud cover changes are in line with changes in the latent heat flux. In $\mathrm{DB}$, the growing season is delayed so that transpiration is reduced by approx. $0.15 \mathrm{~mm} /$ day in May. Evaporation is reduced by more than $0.1 \mathrm{~mm} /$ day in early spring because of lower temperatures. In summer and autumn, an increase in moisture convergence leads to higher soil moisture, so that ET hardly deviates from the control climate. This is in analogy to the situation at the end of the dry period in DT. Similar changes apply for AB but with opposite sign. Annually averaged sensible heat flux anomalies are smaller but of the same sign as the changes in latent heat flux. Outside the latitudes where land cover change was imposed, zonal mean changes in radiative and diffusive fluxes are small.

As in the tropics, the climatic changes contribute to the changes in carbon pools. In contrast to DT and AT however, the impact of temperature on NPP outweighs the $\mathrm{CO}_{2}$ fertilization and the effect of soil moisture, except at the southern edge of the affected area in central Asia. Changes in soil respiration do not contribute significantly to the carbon pool anomalies with the exception of some land cells in eastern Asia and western North America where soil moisture is altered the most.

\subsubsection{Sea ice and circulation feedbacks in boreal latitudes}

The locally induced temperature changes are subject to feedbacks on a larger scale which concern sea-ice cover as well as the oceanic and atmospheric circulation. Although the changes in sea ice cover found here show large fluctuations, differences between the experiments are apparent: In DB, even in the Arctic Ocean the relative increase of sea ice cover is only $0.6 \%$ and not significant in most places in the years $101-300$, although ice volume increases by $10.7 \%$ in this period. In the afforestation experiment, annual mean sea ice cover in the Arctic Ocean is decreased by $2.4 \%$ in the years $101-300$ (1.65\% in 151-300). The slightly stronger response in $\mathrm{AB}$ is most probably due to the fact that the largest albedo changes over land are located in more northern areas than in 

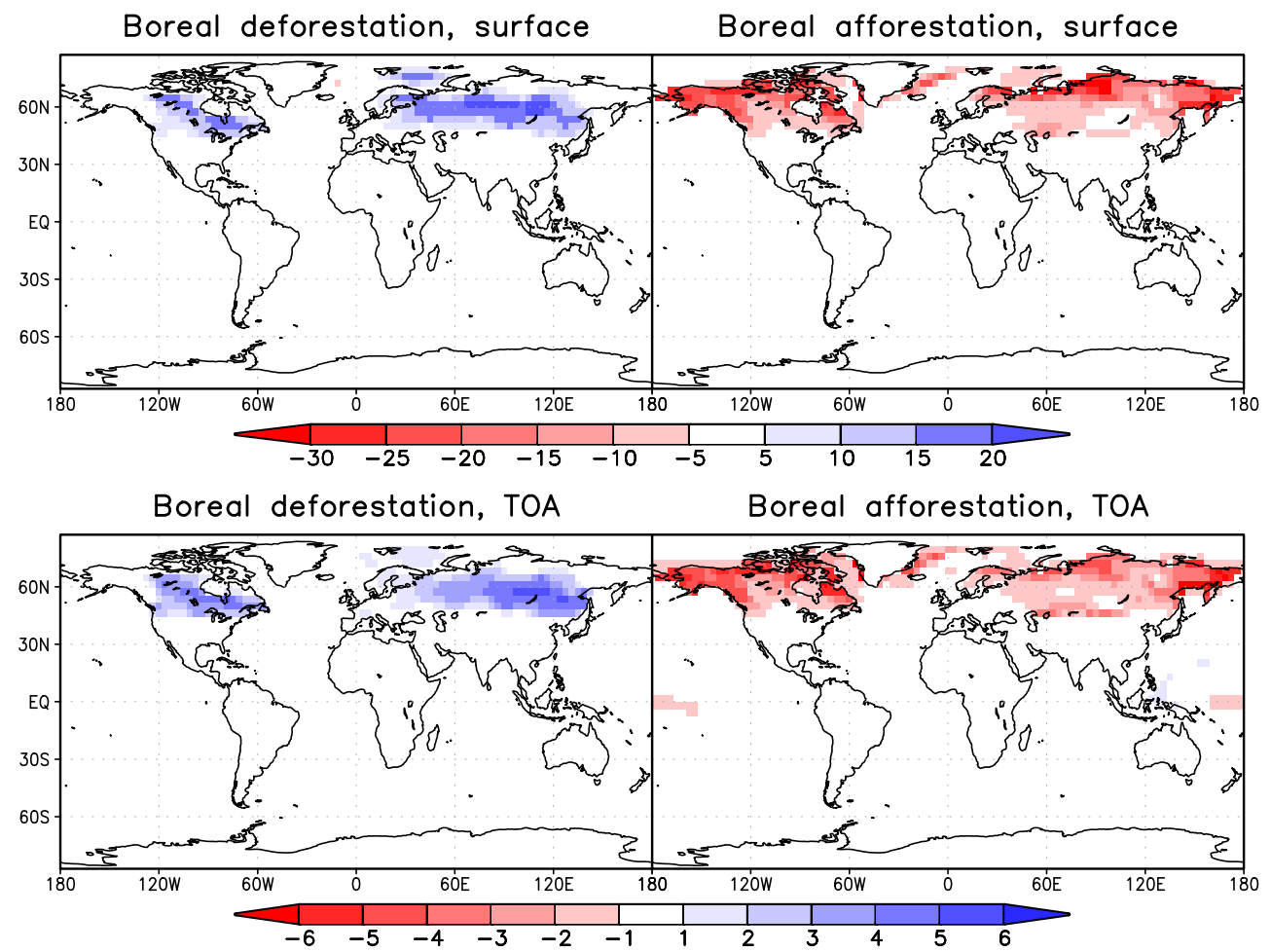

Fig. 11. Anomalies in surface albedo (top) and planetary albedo (bottom) in \%, averaged over the final 200 years for boreal deforestation (left) and boreal afforestation (right).

DB. The difference between $\mathrm{DB}$ and $\mathrm{AB}$ is most discernable in autumn (Fig. 13): although the cooling over the Arctic Ocean in DB is stronger than over the adjacent land in most areas, the geographical pattern of the largest temperature anomalies resembles the short-wave forcing. This is not the case in $\mathrm{AB}$, where the strongest warming occurs in proximity to the Arctic Ocean.

Changes in meridional overturning circulation (MOC) are more pronounced than those in sea ice cover. As Fig. 3 illustrates, the temperature response is weak and in some places even reversed in the north-western Atlantic in both experiments. In DB, the mass flux below $1000 \mathrm{~m}$ is increased by $1.5 \mathrm{~Sv}$ from 15.7 to $17.2 \mathrm{~Sv}$ at $30^{\circ} \mathrm{N}$ on average over the final 200 years; in $\mathrm{AB}$ it is reduced by $1.5 \mathrm{~Sv}$. At $60^{\circ} \mathrm{N}$ however, overturning is strongly enhanced in $\mathrm{DB}$ (from $5.7 \mathrm{~Sv}$ to $6.5 \mathrm{~Sv})$, but hardly affected in $\mathrm{AB}(-0.1 \mathrm{~Sv})$. This may be related to the decrease in ice cover in $\mathrm{AB}$, so that larger buoyancy fluxes than in CTL are obtained. Both, sea ice cover and oceanic circulation changes are reflected in the ET anomalies (Fig. 8), which are of the same order of magnitude as on land.

The boreal land cover changes also influence the atmospheric circulation. In DB the vertically extended cooling leads to an increase in baroclinity and thus in wind speeds in temperate northern latitudes, especially in spring. In $200 \mathrm{hPa}$, a zonal mean increase of up to $1 \mathrm{~m} / \mathrm{s}$ is obtained. In contrast, high level wind speed in the subtropics is decreased in this season over the Atlantic and the Mediterranean. In AB,



Fig. 12. Surface temperature anomalies in ${ }^{\circ} \mathrm{C}$, albedo and snow cover in $\%$, zonally averaged over all land cells during the final 200 years for boreal deforestation (left) and boreal afforestation (right). 

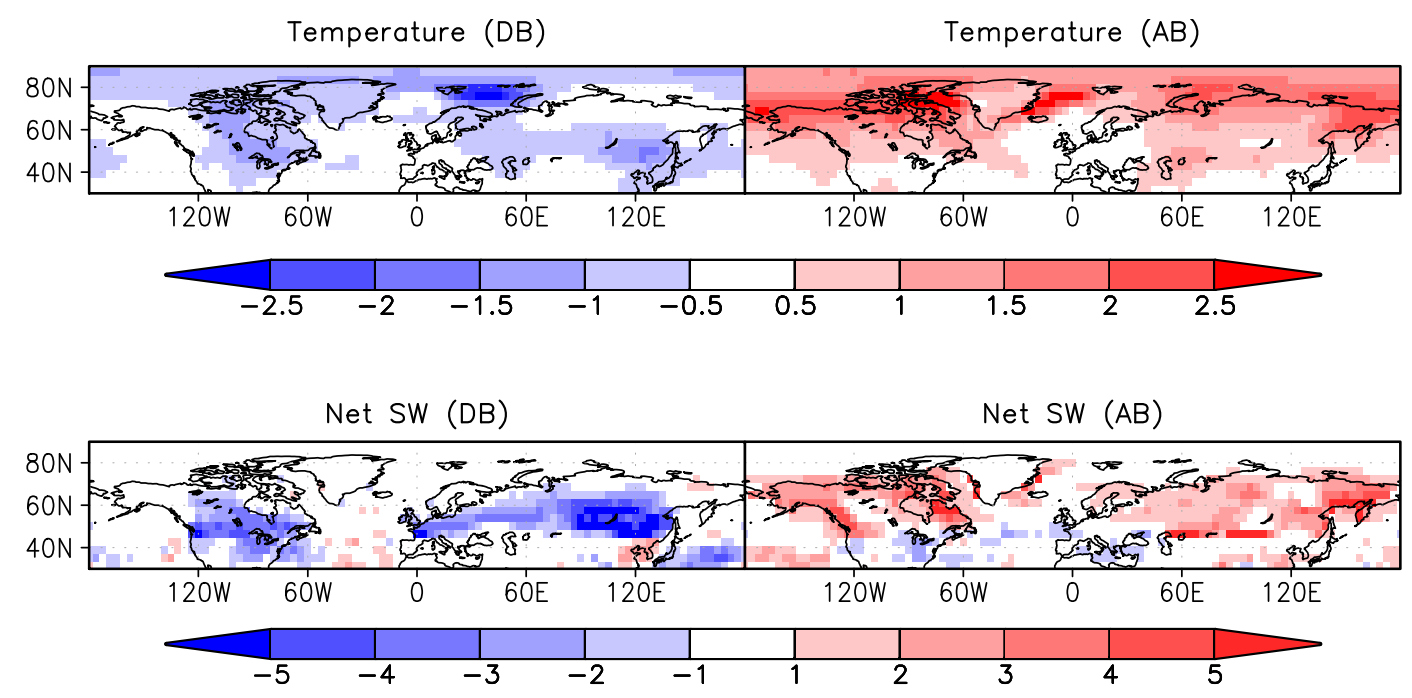

Fig. 13. Anomalies in $2 \mathrm{~m}$-temperature in ${ }^{\circ} \mathrm{C}$ and net short-wave radiation in $\mathrm{W} / \mathrm{m}^{2}$ at the surface for boreal autumn averaged over the final 200 years of the boreal deforestation (left) and boreal afforestation experiment (right).

corresponding zonal mean anomalies are found. However, characteristic deviations from these zonal averages occur. The spatial heterogenity of the surface flux anomalies leads to barotropic Rossby wave patterns which show seasonal variations. In particular, an anticyclonic (cyclonic) anomaly occurs over south-eastern Europe in DB (AB) in spring which shifts to the east during the year. This shift indicates an interaction with a natural pattern: in CTL an anticyclone is simulated over the North Atlantic in spring (Azores high) which shows a similar shift and therefore seems to be extended to the east in $\mathrm{DB}$ and contracted in $\mathrm{AB}$.

\section{Discussion}

\subsection{Tropical experiments}

Many GCM studies on the biogeophysical impact of largescale deforestation in tropical regions have been conducted; a selection is presented in Table 5. Most of these studies show an increase in temperature and a decrease in ET and precipitation, which is in line with the results presented above. In addition, the large-scale sinking in response to the decrease in net energy at the surface is in accordance with expectations (Mylne and Rowntree, 1992; Dirmeyer and Shukla, 1994). The characteristic changes in surface energy balance and cloud cover also agree with CLIMBER-2 results (Ganopolski et al., 2001), with the exception that downwelling long-wave radiation is increased in DT due to $\mathrm{CO}_{2}$ emissions. Changes in moisture convergence and the annual cycle of precipitation are less definite. For example, Nobre et al. (1991), Henderson-Sellers et al. (1993), McGuffie et al. (1995) and Sud et al. (1996) find the largest decrease in Amazonian precipitation during the rainy season, whereas in DT the dry period is intensified in central Amazonia. The comparison with the studies listed in Table 5 is subject to many uncertainties which are introduced by the choice or calculation of surface parameter values (Mylne and Rowntree, 1992; Pitman et al., 1993; Dirmeyer and Shukla, 1994), the treatment of the ocean, different integration times and the definition of areas (McGuffie et al., 1995), as well as the applied model. In addition, no change in $\mathrm{CO}_{2}$ concentration was accounted for in any of these experiments.

However, these differences may not explain why the changes in central Amazonia are much larger than elsewhere. By also using MPI-ESM, but without taking carbon cycle effects into account, Brovkin et al. (2009) find a similarly pronounced warming in Amazonia after global deforestation. Thus, these regional differences might rather be related to regional characteristics such as the amount of water recycling, which is known to be large in Amazonia (Nobre et al., 2004). For example, Pitman et al. (1993), McGuffie et al. (1995) and Zhang et al. (1996) also find the largest reduction of moisture convergence and the strongest (or only) temperature increase in Amazonia (Table 5). Sud et al. (1996) find a large warming and an exceptional decrease in moisture convergence in Amazonia as compared to the tropical mean. Also, Claussen et al. (2001) obtain the strongest warming in South America with CLIMBER-2.

In South East Asia, the water balance is less influenced by local recycling but rather by the monsoon circulation (Zhang et al., 1996). Changes in precipitation and ET are smaller than in Amazonia and the largest relative increase in moisture convergence after deforestation is obtained. In comparison to tropical Africa, absolute ET reduction in DT is larger while the temperature change is similar. The studies listed in Table 5 even report a cooling due to deforestation. Delire et al. (2001) obtained a reduction of SSTs due to increased 
Table 5. Changes in surface temperature $(T)$, precipitation $(P)$, evapotranspiration $(\mathrm{ET})$ and moisture convergence $(P$-ET) in Amazonia (Am), tropical Africa (Af), Indonesia (In), South-Eastern Asia (SEA) and the whole tropics (Trop) in previous (biogeophysical) model studies of large-scale deforestation. Zhang et al. (1996) refer to surface air temperature instead of ground surface temperature. In Pitman et al. (1993) this information is not definite.

\begin{tabular}{|c|c|c|c|c|c|c|}
\hline Publication & Area & Remarks & $\begin{array}{l}\Delta T \\
{\left[{ }^{\circ} \mathrm{C}\right]}\end{array}$ & $\begin{array}{l}\Delta P \\
{[\mathrm{~mm} / \mathrm{yr}]}\end{array}$ & $\begin{array}{l}\Delta \mathrm{ET} \\
{[\mathrm{mm} / \mathrm{yr}]}\end{array}$ & $\begin{array}{l}\Delta(P-\mathrm{ET}) \\
{[\mathrm{mm} / \mathrm{yr}]}\end{array}$ \\
\hline Nobre et al. (1991) & $\mathrm{Am}$ & fixed SST & +2.5 & -643 & -496 & -147 \\
\hline Mylne and Rowntree (1992) & $\mathrm{Am}$ & $\begin{array}{l}z_{0} \text { unchanged, } \\
\text { fixed SST }\end{array}$ & -0.11 & -340 & -179 & -161 \\
\hline $\begin{array}{l}\text { Henderson-Sellers et al. (1993)/ } \\
\text { Pitman et al. (1993) }\end{array}$ & $\mathrm{Am}$ & mixed-layer ocean & +0.6 & -588 & -232 & -356 \\
\hline Polcher and Laval (1994a) & Am & $\begin{array}{l}z_{0} \text { unchanged, } \\
\text { fixed SST }\end{array}$ & +3.8 & +394 & -985 & +1379 \\
\hline Polcher and Laval (1994b) & Am & fixed SST & +0.14 & -186 & -128 & -58 \\
\hline McGuffie et al. (1995) & Am & mixed-layer ocean & +0.3 & -437 & -231 & -206 \\
\hline Sud et al. (1996) & Am & fixed SST & +2.0 & -540 & -445 & -95 \\
\hline Zhang et al. (1996) & Am & mixed-layer ocean & +0.3 & -402 & -222 & -180 \\
\hline Lean and Rowntree (1997) & Am & fixed SST & +2.3 & -157 & -296 & +139 \\
\hline Polcher and Laval (1994a) & Af & $\begin{array}{l}z_{0} \text { unchanged, } \\
\text { fixed SST }\end{array}$ & +2.56 & +88 & -533 & +621 \\
\hline Polcher and Laval (1994b) & Af & fixed SST & +0.03 & -99 & -95 & -4 \\
\hline McGuffie et al. (1995) & Af & mixed-layer ocean & -0.09 & -108 & -89 & -19 \\
\hline Zhang et al. (1996) & Af & mixed-layer ocean & -0.02 & -63 & -74 & +11 \\
\hline Delire et al. (2001) & In & uncoupled & n.s. & -201 & -201 & 0 \\
\hline Polcher and Laval (1994b) & In & fixed SST & -0.05 & -281 & -51 & -230 \\
\hline Pitman et al. (1993) & SEA & mixed-layer ocean & -0.5 & -19 & -113 & +94 \\
\hline McGuffie et al. (1995) & SEA & mixed-layer ocean & -0.69 & -48 & -128 & +80 \\
\hline Zhang et al. (1996) & SEA & mixed-layer ocean & -0.2 & -251 & -138 & -113 \\
\hline Sud et al. (1996) & Trop & fixed SST & +1.3 & -266 & -350 & +84 \\
\hline
\end{tabular}

upwelling. As $\mathrm{CO}_{2}$ concentration is increased in DT, this cannot be expected here. However, a westward anomaly in ocean surface speed occurs during boreal spring and summer due to strengthened trade winds. The increase in SST is relatively low to the west of Indonesian land cells during this period.

In addition to these regional differences, the deforested continents may not be independent of each other. In Amazonia, the anomalies in moisture convergence (Fig. 10) hardly extend to the Pacific because of the Andes, as is also discussed by Lean and Rowntree (1997). In this regard it seems plausible that in Africa the anomalies can affect the nearby ocean more easily. In Fig. 10 a dipole structure is evident over the tropical Atlantic with more moisture convergence north and less moisture convergence south of the equator. This pattern is inherited by precipitation changes between July and October, which reflect a northerly shift of the ITCZ. Anomalies at the eastern boundary of South America could then propagate inland and add to the locally induced changes. However, to determine the extent to which the Amazonian climate is influenced by land cover changes in Africa further studies are needed.

www.biogeosciences.net/7/1383/2010/

\subsection{Boreal experiments}

With regard to the albedo induced cooling in spring and early summer, other GCM-studies of large scale boreal deforestation are qualitatively corroborated. Thomas and Rowntree (1992) as well as Chalita and LeTreut (1994) analysed the impact of albedo differences between closed snow cover and snow-covered forest. The temperature changes in MPIESM are similar to their results. Douville and Royer (1997) used the ARPEGE climate model and additionally considered the change in roughness length. They found a temperature maximum of more than $3^{\circ} \mathrm{C}$ in April and May between $50^{\circ} \mathrm{N}$ and $60^{\circ} \mathrm{N}$, similar to MPI-ESM. However, the duration of the cooling is much less than reported by Douville and Royer: while they found a cooling of more than $2{ }^{\circ} \mathrm{C}$ between December and June in the same latitudes, a comparable anomaly only persists for 3 months in MPI-ESM (Fig. 12). One reason might be the delayed snow melt in ARPEGE.

It must be considered though, that in all three studies there was no coupling between atmosphere and ocean. Bonan et al. (1992) and Ganopolski (2001) showed that if taking the ocean into account, the cooling is stronger, more evenly 
distributed over the year and geographically more extended. Bonan et al. (1992) found a cooling of locally up to $5^{\circ} \mathrm{C}$ in July and $12{ }^{\circ} \mathrm{C}$ in April. Snyder et al. (2004) obtained a cooling of $2.8^{\circ} \mathrm{C}\left(6.2^{\circ} \mathrm{C}\right.$ in MAM $)$ even with fixed SSTs because of a strong increase in low level cloudiness. As MPIESM includes the interaction with the ocean, the simulated temperature decrease in DB is much less than anticipated by comparison with other studies. The choice of replacement vegetation, changes in $\mathrm{ET}$ and the additional $\mathrm{CO}_{2}$ of $5 \mathrm{ppm}$ can not account for this difference. In contrast, large discrepancies to other models are apparent in the short-wave fluxes. Douville and Royer (1997) find a reduction of net short-wave radiation at the surface of more than $20 \mathrm{~W} / \mathrm{m}^{2}$ between $50^{\circ} \mathrm{N}$ and $65^{\circ} \mathrm{N}$ in March and April. In MPI-ESM the maximum value amounts to only $15 \mathrm{~W} / \mathrm{m}^{2}$. Bonan et al. (1995) and Thomas and Rowntree (1992) report an annual mean decrease in net radiation of $20-40 \mathrm{~W} / \mathrm{m}^{2}$, the latter 30 $50 \mathrm{~W} / \mathrm{m}^{2}$ in April and May. Snyder et al. (2004) also found a decrease of $30 \mathrm{~W} / \mathrm{m}^{2}$ in MAM. As these values are generally averaged over different areas and time periods and represent different components of the surface radiative balance, the comparison cannot be perfectly consistent. However, it seems obvious that the sensitivity of the short-wave radiative balance to land cover change in high latitudes is comparatively weak in MPI-ESM. The reason seems to be related to the parameterisation of surface albedo: In comparison to observations from the BOREAS study, presented in Betts and Ball (1997), the albedo of snow-covered forests is too high in MPI-ESM. This is especially the case for deciduous forest, for which Betts and Ball find an albedo of 0.21 , while in the model the values lie in the range of 0.4-0.7. For boreal evergreen forest, Betts and Ball state a mean of 0.13 ; in the model a range of $0.2-0.45$ is found. Even in the boreal afforestation case, where maximal forest cover is assumed, albedo values are between 0.2 and 0.25 . Also, measurements indicate that snow masking by deciduous and evergreen forest is similar (Betts and Ball, 1997; Robinson and Kukla, 1984). This is apparently not the case in MPI-ESM, although stems and branches are accounted for by a stem area index.

It seems plausible that the small change in sea ice cover in the boreal experiments is at least partly due to the weak temperature response in MPI-ESM. Ganopolski et al. (2001) found a $20 \%$ increase in global sea ice cover due to boreal deforestation in CLIMBER-2. They also came to the conclusion that the thermal lag of the ocean and the ice-albedo feedback are the main reasons for a cooling in summer. This seems to be true for the autumn in AB, but not DB (Fig. 13). Results are not as distinct for the summer months. In contrast, the MOC increase of $1.5 \mathrm{~Sv}$ in DB agrees well with the $2 \mathrm{~Sv}$ obtained by Ganopolski et al. (2001). However, the diversity of model differences makes a causal assessment difficult. This also applies for atmospheric circulation changes. It is striking, that Douville and Royer (1997) also found a disturbance of the formation of the Azores High due to boreal deforestation. However, the similarities to their results are very limited, as Douville and Royer (1997) found a delayed rather than an earlier high. Also, they report weakened westerlies over northern Europe and Russia, a southward shift of the North Atlantic westerly jet, increased surface pressure in high latitudes and reduced surface pressure over the midlatitude Atlantic. All these features are of opposite sign in this study. A similarity can be found in the weakening of the Indian summer monsoon winds in DB, although this is not accompanied by a reduction in precipitation as in Douville and Royer (1997).

\subsection{Global sensitivities}

In order to assess the impact of forest cover changes independently of the area's size, Table 6 presents the sensitivity of global mean temperature and $\mathrm{CO}_{2}$ content to changes in forest area. These can be compared to Claussen et al. (2001) who present a similar analysis for CLIMBER-2 in Fig. 1 of their study. The areas $10^{\circ} \mathrm{N}-20^{\circ} \mathrm{N}$ and $40^{\circ} \mathrm{N}-50^{\circ} \mathrm{N}$ in Claussen et al. (2001) are weighted only half here in order to account for the different choices of latitude bands.

Although CLIMBER-2 and MPI-ESM differ in many respects, the results are qualitatively similar. Nonetheless, with the exception of tropical deforestation, $\mathrm{CO}_{2}$ sensitivities are smaller in MPI-ESM. In AT, the unproductive climate of dry regions prevents a larger $\mathrm{CO}_{2}$ uptake, a feature that may not be as important in CLIMBER-2 because of the low resolution. In the case of boreal afforestation it must be considered that the carbon cycle had not yet reached a new equilibrium due to the shorter integration time. The low $\mathrm{CO}_{2}$-sensitivity of MPI-ESM to boreal deforestation is due to the low carbon storages of above ground biomass. However, this deficiency seems to be cancelled by the weak snow masking so that temperature sensitivities in high latitudes are similar in both studies. In the tropics, the differences in the sensitivity of temperature seem to reflect those in $\mathrm{CO}_{2}$ content. $\mathrm{As} \mathrm{CO}_{2}$ concentration in DT is still decreasing in the year 300, sensitivities for this experiment are probably not well comparable.

In comparison to Bala et al. (2007), temperature changes are small in both deforestation experiments. The global warming of $0.7^{\circ} \mathrm{C}$ in the year 100 after tropical deforestation in Bala et al. (2007) may be related to larger carbon pools in INCCA. The corresponding $\mathrm{CO}_{2}$ anomaly of $199 \mathrm{ppm}$ is approx. 4 times larger than in MPI-ESM. In response to boreal deforestation, $\mathrm{CO}_{2}$ anomalies are similar in both models, but albedo changes and thus global cooling are much more pronounced in INCCA. Nonetheless, the signs of global mean temperature changes obtained here are in line with the results of Bala et al. (2007), and for boreal latitudes also with Betts (2000).

With regard to the discrepancies between the terrestrial carbon pools in MPI-ESM and observations the question arises how realistic the temperature sensitivities in Table 6 are. As MPI-ESM's climate sensitivity is approx. $3{ }^{\circ} \mathrm{C}$ (Friedlingstein et al., 2006), the $\mathrm{CO}_{2}$ increase by some ppm 
Table 6. Sensitivities of temperature and $\mathrm{CO}_{2}$ in comparison with Claussen et al. (2001), averaged over the final 150 years. In the case of tropical deforestation, the $\mathrm{CO}_{2}$ anomaly was averaged over the final 30 years.

\begin{tabular}{lllll}
\hline Experiment & DT & AT & DB & AB \\
\hline Converted area in million $\mathrm{km}^{2}$ & -23.07 & +10.52 & -18.55 & +26.72 \\
$\mathrm{CO}_{2}$ anomaly in ppm & +26.8 & -4.0 & +3.7 & -6.5 \\
$\mathrm{CO}_{2}$ sensitivity in ppm/million km ${ }^{2}$ & -1.16 & -0.38 & -0.20 & -0.24 \\
$\mathrm{CO}_{2}$ sensitivity in Claussen et al. (2001) & -0.83 & -0.97 & -0.60 & -0.40 \\
Temperature anomaly in $^{\circ}$ & +0.4 & -0.06 & -0.25 & +0.26 \\
Temperature sensitivity in ${ }^{\circ} \mathrm{C} /$ million km $^{2}$ & -0.017 & -0.006 & +0.013 & +0.010 \\
Temperature sensitivity in Claussen et al. (2001) & -0.010 & -0.010 & +0.015 & +0.010 \\
\hline
\end{tabular}

in DB should translate into only some hundredth ${ }^{\circ} \mathrm{C}$ on global average, so the biogeophysical effects prevail by almost one order of magnitude. If boreal vegetation carbon pools are assumed to be as large as the observations, boreal deforestation would still lead to a cooling. The same argument applies for boreal afforestation. The assumption of linearity seems to be justified, as in Claussen et al. (2001) and Bala et al. (2007) synergies between biogeophysical and biogeochemical effects are found to be small. As mentioned in Sect. 2, observations also indicate less tropical soil carbon than is obtained in MPI-ESM. After deforestation, the secondary emissions from tropical soils amount to approx. $150 \mathrm{GtC}$, if the contribution of the living biomass, which has been partly put into the soil pools, is subtracted. If a reduction in equilibrium soil carbon by a factor of 2 is assumed, the secondary emissions would be reduced by $75 \mathrm{GtC}$. This would translate into a reduction in atmospheric $\mathrm{CO}_{2}$ concentration by about $10 \mathrm{ppm}$, as the airborn fraction of tropical emissions is between $45 \%$ and $15 \%$ during the experiment. This relatively small difference in $\mathrm{CO}_{2}$ cannot significantly alter the obtained global warming. As tropical soil carbon is also decreased after afforestation, a reduction in equilibrium soil pools and thus $\mathrm{CO}_{2}$ emissions would tend to cool the planet even more in AT. It can therefore be concluded that the sign of the obtained temperature changes is robust in spite of the significant uncertainties in terrestrial carbon pools.

However, uncertainties also remain concerning the role of individual processes. Claussen et al. (2001) as well as Bala et al. (2007) find a cooling biogeophysical contribution of tropical deforestation. The latter suggest that the albedo change dominates over the reduced ET in its impact on temperature because the ET of grass in INCCA is comparatively high. As the changes in tropical surface temperature and the energy balance demonstrate, this is not the case in MPI-ESM. Claussen et al. (2001) also obtain a warming at tropical land cells, even though it is counteracted on a global scale by the diminished greenhouse effect, resulting from reduced ET. In agreement with this, Ganopolski et al. (2001) report a warming over tropical land and cooling over the oceans. As only coupled experiments have been conducted here, it cannot be determined whether this holds true for MPI-ESM.

\section{Summary and conclusions}

The experiments presented here show that in MPI-ESM forests tend to warm the surface in high northern latitudes but act to cool the surface in the tropics. Earlier model studies are corroborated by this result. A global temperature change of $+0.4{ }^{\circ} \mathrm{C}$ and a $\mathrm{CO}_{2}$ anomaly of initially $60 \mathrm{ppm}$ is obtained after tropical deforestation because of large primary and secondary carbon emissions. In addition, the strong reduction in evapotranspiration leads to a pronounced warming in tropical land areas. While this is in line with the majority of biogeophysical GCM-studies, changes in the annual cycle and moisture convergence remain uncertain. For tropical afforestation, results are opposite to the deforestation experiment, but of much smaller magnitude, because productivity remains low in dry areas. $\mathrm{CO}_{2}$ as well as global mean temperature are therefore hardly affected. In high latitudes the snow masking of trees in spring dominates the temperature response, although this effect is weaker than in other models. Changes in sea ice cover, meridional overturning in the ocean as well as atmospheric circulation modify the temperature anomalies, but the contribution of these feedbacks is also model dependent. Primary and secondary emissions are low in DB compared to DT because biomass pools and productivity differences between grass and trees are small. In the case of boreal afforestation, the large carbon sink is quickly cancelled by the ocean and tropical forests. $\mathrm{CO}_{2}$ anomalies therefore do not exceed some ppm in both boreal experiments. Despite many model differences, the order of magnitude of global temperature and $\mathrm{CO}_{2}$ sensitivities is similar to CLIMBER-2 results from Claussen et al. (2001).

For some land cells, a negative relation between forest cover and carbon storage is obtained, although they do not dominate the spatial mean in any experiment. Also, local temperature changes opposite to the global mean occur due to local differences in surface properties or feedbacks. This is mostly the case in Africa, where afforestation resulted in a warming in places with high surface albedo. Because of the dry conditions there, an afforestation would certainly not be feasible in reality. Nonetheless, as realistic afforestation or reforestation projects must always be confined to much 
smaller areas than considered here, the spatial mean sensitivities do not apply in such cases. The magnitude and even the sign of biogeophysical and biogeochemical effects may then depend on the location. Therefore, studies such as Bird et al. (2008) and Montenegro et al. (2009), who challenge the idea of a warming boreal forest might be valid on a local scale and different from large-scale experiments.

In addition, many model limitations exist. In high latitudes, these primarily consist in the albedo of snow-covered forest. The representation of soil moisture as a single bucket neglects many important aspects such as the root depth of different plants. This may be particularly inadequate in the tropics, where changes in the water cycle are essential. As soil moisture has shown a large impact on productivity and soil respiration in the experiments, these uncertainties also affect the carbon cycle. In addition, neither the actual size of soil carbon pools nor the dependencies of NPP on temperature, soil moisture and atmospheric $\mathrm{CO}_{2}$ as well as the dependency of soil respiration on temperature and moisture are constrained well and thus differ among models (Friedlingstein et al., 2006). As these mechanisms can act in opposite directions, the net effect on carbon pools may thus also be model dependent. In order to assess the impacts of forest cover changes in a more appropriate way, a better quantification of these effects from observations is therefore essential.

Acknowledgements. We would like to thank our anonymous reviewers as well as Hauke Schmidt for their useful comments. Robert Schoetter is gratefully acknowledged for his lunchtime lessons.

The service charges for this open access publication have been covered by the Max Planck Society.

Edited by: T. Laurila

\section{References}

Alton, P.: A simple retrieval of ground albedo and vegetation absorptance from MODIS satellite data for parameterisation of global land-surface models, Agr. Forest Meteorol., 149, 17691775, 2009.

Bala, G., Caldeira, K., Wickett, M., Phillips, T. J., Lobell, D. B., Delire, C., and Mirin, A: Combined climate and carbon-cycle effects of large-scale deforestation, P. Natl. Acad. Sci. USA, 104, 6550-6555, 2007.

Betts, A. K. and Ball, J. H.: Albedo over the boreal forest, J. Geophys. Res., 102, 28901-28909, 1997.

Betts, R. A., Cox, P. M., Lee, S. E., and Woodward, F. I.: Contrasting physiological and structural vegetation feedbacks in climate change simulations, Nature, 387, 796-799, 1997.

Betts, R. A.: Offset of the potential carbon sink from boreal forestation by decreases in surface albedo, Nature, 408, 187-190, 2000.

Bird, D. N., Kunda, M., Mayer, A., Schlamadinger, B., Canella, L., and Johnston, M.: Incorporating changes in albedo in estimating the climate mitigation benefits of land use change projects, Biogeosciences Discuss., 5, 1511-1543, 2008, http://www.biogeosciences-discuss.net/5/1511/2008/.

Bonan, G. B., Pollard, D., and Thompson, S. L.: Effects of boreal forest vegetation on global climate, Nature, 359, 716-718, 1992.

Bonan, G. B., Chapin III, F. S., and Thompson, S. L.: Boreal forest and tundra ecosystems as components of the climate system, Climatic Change, 29, 145-167, 1995

Brovkin, V., Claussen, M., Driesschaert, E., Fichefet, T., Kicklighter, D., Loutre, M. F., Matthews, H. D., Ramankutty, N., Schaeffer, M., and Sokolov, A.: Biogeophysical effects of historical land cover changes simulated by six earth system models of intermediate complexity, Clim. Dynam., 26, 587-600, 2006.

Brovkin, V., Raddatz, T., Reick, C. H., Claussen, M., and Gayler, V.: Global biogeophysical interactions between forest and climate, Geophys. Res. Lett., 36, L07405, doi:10.1029/2009GL037543, 2009.

Chalita, S. and Le Treut, H.: The albedo of temperate and boreal forest and the northern hemisphere climate: a sensitivity experiment using the LMD GCM, Clim. Dynam., 10, 231-240, 1994.

Claussen, M., Brovkin, V., and Ganopolski, A.: Biogeophysical versus biogeochemical feedbacks of large-scale land cover change, Geophys. Res. Lett., 28, 1011-1014, 2001.

Collatz, G. J., Ribas-Carbo, M., and Berry, J. A.: Coupled photosynthesis-stomatal conductance model for leaves of $\mathrm{C} 4$ plants, Aust. J. Plant Physiol., 19, 519-538, 1992.

Delire, C., Behling, P., Coe, M. T., Foley, J. A., Jacob, R., Kutzbach, J., Liu, Z., and Vavrus, S.: Simulated response of the atmosphere-ocean system to deforestation in the Indonesian Archipelago, Geophys. Res. Lett., 28, 2081-2084, 2001.

Dirmeyer, P. A. and Shukla, J.: Albedo as a modulator of climate response to tropical deforestation, J. Geophys. Res., 99, 2086320877, 1994.

Douville, H. and Royer, J.-F.: Influence of the temperate and boreal forests on the northern hemisphere climate in the Météo-France climate model, Clim. Dynam., 13, 57-74, 1997.

Farquhar, G. D., von Caemmerer, S., and Berry, J. A.: A Biochemical Model of Photosynthetic $\mathrm{CO}_{2}$ Assimilation in Leaves of C3 Species, Planta, 149, 78-90, 1980.

Friedlingstein, P., Cox, P., Betts, R., Bopp, L., von Bloh, W., Brovkin, V., Cadule, P., Doney, S., Eby, M., Fung, I., Bala, G., John, J., Jones, C., Joss, F., Kato, T., Kawamiya, M., Knorr, W., Lindsay, K., Matthews, H. D., Raddatz, T., Rayner, P., Reick, C., Roeckner, E., Schnitzler, K.-G., Schnur, R., Strassmann, K., Weaver, A. J., Yoshikawa, C., and Zeng, N.: Climate-Carbon Cycle Feedback Analysis: Results from the C4MIP Model Intercomparison, J. Climate, 19, 3337-3353, 2006.

Ganopolski, A., Petoukhov, V., Rahmstorf, S., Brovkin, V., Claussen, M, Eliseev, A., and Kubatzki, C.: CLIMBER-2: a climate system model of intermediate complexity. Part II: model sensitivity, Clim. Dynam., 17, 735-751, 2001.

Henderson-Sellers, A., Dickinson, R. E., Durbidge, T. B., Kennedy, P. J., McGuffie, K., and Pitman, A. J.: Tropical deforestation: Modeling local- to regional-scale climate change, J. Geophys. Res., 98, 7289-7315, 1993.

House, J. I., Prentice, I. C., and Le Quere, C.: Maximum impacts of future reforestation or deforestation on atmospheric $\mathrm{CO}_{2}$, Glob. Change Biol., 8, 1047-1052, 2002. 
Jungclaus, J. H., Keenlyside, N., Botzet, M., Haak, H., Luo, J.-J., Latif, M., Marotzke, J., Mikolajewicz, U., and Roeckner, E.: Ocean circulation and tropical variability in the coupled model ECHAM5/MPI-OM, J. Climate, 19, 3952-3972, 2006.

Lean, J. and Rowntree, P. R.: Understanding the sensitivity of a GCM simulation of Amazonian deforestation to the specification of vegetation and soil characteristics, J. Climate, 10, 1216-1235, 1997.

Maier-Reimer, E., Kriest, I., Segschneider, J., and Wetzel, P.: The HAMburg Ocean Carbon Cycle model HAMOCC 5.1 - Technical description, Release 1.1, Technical report 14/2005, MaxPlanck Institute for Meteorology, Hamburg, 2005.

Matthews, H. D., Weaver, A. J., Meissner, K. J., Gillet, N. P., and Eby, M.: Natural and anthropogenic climate change: incorporating historical land cover change, vegetation dynamics and the global carbon cycle, Clim. Dynam., 22, 461-479, 2004.

McGuffie, K., Henderson-Sellers, A., Zhang, H., Durbridge, T. B., and Pitman, A. J.: Global climate sensitivity to tropical deforestation, Global Planet. Change, 10, 97-128, 1995. v Montenegro, A., Eby, M., Mu, Q., Mulligan, M., Weaver, A. J., Wiebe, E. C., and Zhao, M.: The net carbon drawdown of small scale afforestation from satellite observations, Global Planet. Change, 69, 195-204, 2009.

Mylne, M. F. and Rowntree, P. R.: Modelling the effects of albedo change associated with tropical deforestation, Climatic Change, 21, 317-343, 1992.

Nobre, C. A., Sellers, P. J., and Shukla, J.: Amazonian deforestation and regional climate change, J. Climate, 4, 957-988, 1991.

Nobre, C. A., Silva Dias, M. A., Culf, A. D., Polcher, J., Gash, J. H. C., Marengo, J. A., and Avissar, R.: The Amazonian climate, in: Vegetation, Water, Humans and the Climate: A New Perspective on an Interactive System, Springer, Berlin, Heidelberg, 79-92, 2004.

Pielke Sr., R. A., Avissar, R., Raupach, M., Dolman, A. J., Zeng, X., and Denning, A. S.: Interactions between the atmosphere and terrestrial ecosystems: influence on weather and climate, Glob. Change Biol., 4, 461-475, 1998.

Pielke Sr., R. A., Marland, G., Betts, R. A., Chase, T. N., Eastman, J. L., Niles, J. O., Niyogi, D. S., and Running, S. W.: The influence of land-use change and landscape dynamics on the climate system: relevance to climate-change policy beyond the radiative effect of greenhouse gases, Philos. T. R. Soc. Lond., 360, 1705$1719,2002$.

Pitman, A. J., Durbridge, T. B., Henderson-Sellers, A., and McGuffie, K.: Assessing climate model sensitivity to prescribed deforested landscapes, Int. J. Climatol., 13, 879-898, 1993.

Pitman, A. J., Dolman, H., Kruijt, B., Valentini, R., and Baldocchini, D.: The climate near the ground, in: Vegetation, Water, Humans and the Climate: A New Perspective on an Interactive System, Springer, Berlin, Heidelberg, 9-19, 2004.
Polcher, J. and Laval, K.: The impact of African and Amazonian deforestation on tropical climate, J. Hydrol., 155, 389-405, 1994a.

Polcher, J. and Laval, K.: A statistical study of the regional impact of deforestation on climate in the LMD GCM, Clim. Dynam., 10, 205-219, 1994b.

Prentice, I., Farquhar, G., Fasham, M., Goulden, M., Heimann, M., Jaramillo, V., Kheshgi, H., Le Quere, C., Scholes, R., and Wallace, D.: The carbon cycle and atmospheric carbon dioxide. In: Climate change 2001: The scienti?c basis. Contribution of Working Group I to the Third Assessment Report of the Intergovernmental Panel on Climate Change, edited by: Houghton, J. T., Ding, Y., Griggs, D. J., Noguer, M., van der Linden, P., Dai, X., Maskell, K., and Johnson, C. I., Cambridge University Press, Cambridge, 183-237, 2001.

Raddatz, T. J., Reick, C. H., Knorr, W., Kattge, J., Roeckner, E., Schnur, R., Schnitzler, K.-G., Wetzel, P., and Jungclaus, J.: Will the tropical land biosphere dominate the climate-carbon cycle feedback during the twenty-first century?, Clim. Dynam., 29, 565-574, 2007.

Robinson, D. A. and Kukla, G.: Albedo of a dissipating snow cover, J. Clim. Appl. Meteorol., 23, 1626-1634, 1984.

Roeckner, E., Baeuml, G., Bonaventura, L., Brokopf, R., Esch, M., Giorgetta, M., Hagemann, S., Kirchner, I., Kornblueh, L., Manzini, E., Rhodin, A., Schlese, U., Schulzweida, U., and Tompkins, A.: The atmospheric general circulation model ECHAM5. Part I: Model description, Max-Planck Institute for Meteorology, Report 349, 2003.

Schaeffer, M., Eickhout, B., Hoogwijk, M., Strengers, B., van Vuuren, D., Leemans, R., and Opsteegh, T.: $\mathrm{CO}_{2}$ and albedo climate impacts of extratropical carbon and biomass plantations, Global Biogeochem. Cy., 20, GB2020, doi:10.1029/2005GB002581, 2006.

Snyder, P. K., Delire, C., and Foley, J. A.: Evaluating the influence of different vegetation biomes on the global climate, Clim. Dynam., 23, 279-302, 2004.

Spracklen, D. V., Bonn, B., and Carslaw, K. S.: Boreal forests, aerosols and the impacts on clouds and climate, Philos. T. R. Soc. A, 366, 4613-4626, 2008.

Sud, Y. C., Walker, G. K., Kim, J.-H., Liston, G. E., Sellers, P. J., and Lau, W. K.-M.: Biogeophysical consequences of a tropical deforestation scenario: a GCM simulation study, J. Climate, 9, 3225-3247, 1996.

Thomas, G. and Rowntree, P. R.: The boreal forests and climate, Q. J. Roy. Meteor. Soc., 118, 469-497, 1992.

Zhang, H., Henderson-Sellers, A., and McGuffie, K.: Impacts of tropical deforestation. Part I: Process analysis of local climatic change, J. Climate, 9, 1497-1517, 1996. 